\title{
The genera Helvella and Dissingia (Ascomycota: Pezizomycetes) in Europe - Notes on species from Spain
}

\author{
I. Skrede ${ }^{1 *}$, L. Ballester Gonzalvo ${ }^{2}$, C. Mathiesen ${ }^{1}$, T. Schumacher ${ }^{1}$ \\ ${ }^{1}$ Department of Biosciences, University of Oslo, P.O. Box 1066, 0316 Oslo Norway \\ ${ }^{2}$ Calle Octavio de Toledo 25, 50007, Zaragoza, Spain \\ *Corresponding author: inger.skrede@ibv.uio.no
}

Key words:

Helvella

molecular phylogeny

new taxa

Pezizales

\begin{abstract}
Phylogenetic analyses of 115 newly collected Helvella specimens from Spain using three genetic markers [heat shock protein 90 ( $h s p)$, RNA polymerase II second largest subunit ( $r p b 2)$ and the nuclear large subunit ribosomal DNA (LSU)] confirm the assignment of the Spanish collections to one Dissingia and 30 Helvella species. The analyses were supplemented with an additional sample of 65 Spanish and extralimital Helvella specimens from the fungaria of Oslo (O), Trondheim (TRH), Copenhagen (C), Uppsala (UPS), Stockholm (S) and Venice (MCVE). Nine species are described as new, i.e. Helvella fuscolacunosa, $H$. hispanica, $H$. iberica, $H$. inexpectata, $H$. neopallescens, $H$. phlebophoroides, $H$. poculiformis, $H$. retinervis, and $H$. terricola. We present photographs of a selection of fresh specimens and provide descriptions of all species of this diverse South European Mediterranean element of the genera in Europe.
\end{abstract}

Citation: Skrede I, Ballester Gonzalvo L, Mathiesen C, Schumacher T (2020). The genera Helvella and Dissingia (Ascomycota: Pezizomycetes) in Europe - Notes on species from Spain. Fungal Systematics and Evolution 6: 65-93. doi: 10.3114/fuse.2020.06.05

Effectively published online: 3 April 2020

Corresponding editor: P.W. Crous

\section{INTRODUCTION}

Helvella is a species-rich genus of apothecial ascomycetous fungi (Pezizomycetes: Pezizales: Helvellaceae) of terrestrial biomes of the northern and southern hemispheres. Many authors have contributed to the species-level taxonomy of the genus, the more comprehensive are those of Boudier (1905-1910), Nannfeldt (1932, 1937), Dissing (1966a, b, Dissing \& Nannfeldt 1966), Weber (1972, 1975), Harmaja (1977b, 1979), Häffner (1987), Abbott \& Currah (1997), Vooren (2010, 2014), Landeros et al. (2012, 2015), and Skrede et al. (2017). In Dissing's monograph of "The genus Helvella in Europe" (Dissing 1966a), he recognised 26 species in Europe, a list that was later expanded to 28 (Dissing 1972 ) and to 38 in a survey $30 \mathrm{yr}$ later, but then confined to species of the Nordic countries only (Dissing 2000). Meanwhile, Häffner (1987) accepted 41 species of Helvella from Germany and the European continent.

In a preceding study by Skrede et al. (2017), we used a multilocus genealogical approach to re-assess species limits, phylogeny and species-level taxonomy within the genus. Based on a selection of fungarium collections and newly collected specimens from North and Central Europe, Skrede et al. (2017) assigned molecular specifics and morphological characteristics to altogether 55 phylogenetic species of Helvella in Europe. In that work, however, specimens from Southern Europe were seriously under-represented. This paved the way for a review of Helvella specimens from Southern Europe using sequence data. The present work adds nine species to the checklist of Helvellaspecies from the European continent.
In a recent account on the generic limits and phylogeny of the family Helvellaceae, Hansen et al. (2019) erected the segregate genus Dissingia to encompass the morphological and molecular distinct members, previously recognised as the /leucomelaena lineage of Helvella sensu lato (Landeros et al. 2015, Skrede et al. 2017). This genus has been included in this revisionary study.

Calonge \& Arroyo (1990) published an annotated species list of the genus Helvella in Spain, following the species concepts in Dissing (1966b). Their material, deposited at the fungarium of the Botanic Garden of Madrid, comprised 22 species and one variety assumed to include all species that occurred in the country. For a survey of early studies on Spanish Helvella species, the reader is referred to the introductory notes and bibliography presented in the work by Calonge \& Arroyo (1990).

\section{MATERIALS AND METHODS}

Table 1 summarises Spanish and extralimital samples of Helvella specimens included in this study that are deposited in the fungaria of Copenhagen (C), Oslo (O), Sociedad de Ciencias Aranzadi (ARAN), Stockholm (S), Trondheim (TRH), Uppsala (UPS), and Venice (MCVE). In addition, Dissingia leucomelaena specimens from Spain were included as a suitable outgroup in the phylogenetic analyses. A selection of in situ photographs of typical specimens of all species of the Spanish specimens is given.

The morphological analyses follow the outline in Skrede et al. (2017). For the ascospore measurements, 10 ejected mature 
Table 1. Locality, identification, and type information for Helvella and Dissingia specimens included in the study. The ID column contains type information and sequencing fungarium identification numbers. The columns LSU, $h s p$ and rpb2 contain GenBank accession numbers. Accession numbers in italics are new accessions from this study, accession numbers in bold are included in maximum likelihood analyses resulting in Fig. 1.

\begin{tabular}{|c|c|c|c|c|c|c|c|}
\hline Species & ID & LSU & hsp & $r p b 2$ & Locality & Coll. date & $\begin{array}{l}\text { Collector - } \\
\text { Collector ID }\end{array}$ \\
\hline \multirow[t]{7}{*}{ D. leucomelaena } & H1930 (O-F-256543) & - & MN598130 & MN626787 & $\begin{array}{l}\text { Spain, Navarra, } \\
\text { Viana }\end{array}$ & 12.03 .2016 & $\begin{array}{l}\text { A. Ezquerro - } \\
\text { AEA0010 }\end{array}$ \\
\hline & H1931 (O-F-256544) & - & MN598131 & MN626788 & $\begin{array}{l}\text { Spain, Rioja, } \\
\text { Logrono }\end{array}$ & 11.03 .2017 & $\begin{array}{l}\text { A. Ezquerro, } \\
\text { L. Ballester - } \\
\text { LB17031101 }\end{array}$ \\
\hline & H2893 (TRH-12606) & - & MN598183 & - & $\begin{array}{l}\text { Spain, Balearic } \\
\text { Islands, Mallorca, } \\
\text { Galilea }\end{array}$ & 29.12.1997 & S. Sivertsen \\
\hline & H2894 (TRH-12615) & - & MN598184 & - & $\begin{array}{l}\text { Spain, Balearic } \\
\text { Islands, Mallorca, } \\
\text { Galilea }\end{array}$ & 29.12.1987 & S. Sivertsen \\
\hline & H2896 (TRH-12619) & - & MN598186 & - & $\begin{array}{l}\text { Spain, Balearic } \\
\text { Islands, Mallorca, } \\
\text { Lluch }\end{array}$ & 08.04.1982 & S. Sivertsen \\
\hline & H2898 (TRH-12628) & - & MN598187 & - & $\begin{array}{l}\text { Spain, Balearic } \\
\text { Islands, Mallorca, } \\
\text { Son Torrella }\end{array}$ & 28.01.1979 & S. Sivertsen \\
\hline & H2899 (TRH-12629) & - & MN598188 & - & $\begin{array}{l}\text { Spain, Balearic } \\
\text { Islands, Mallorca, } \\
\text { Son Torrella }\end{array}$ & 28.01.1979 & S. Sivertsen \\
\hline \multirow{7}{*}{ H. acetabulum } & H1934 (O-F-256512) & - & MN598134 & - & $\begin{array}{l}\text { Spain, Zaragoza, } \\
\text { Paniza }\end{array}$ & 30.04 .2006 & $\begin{array}{l}\text { L. Ballester - } \\
\text { LB06043001 }\end{array}$ \\
\hline & H1935 (O-F-256513) & - & MN598135 & - & $\begin{array}{l}\text { Spain, Rioja, } \\
\text { Banos de Rio Tobia }\end{array}$ & 02.04 .2016 & $\begin{array}{l}\text { A. Ezquerro - } \\
\text { AEA0026 }\end{array}$ \\
\hline & H1936 (O-F-256514) & - & MN598136 & - & $\begin{array}{l}\text { Spain, Girona, S. } \\
\text { Marti d'Empuries }\end{array}$ & 12.03 .2017 & $\begin{array}{l}\text { M. Perez de } \\
\text { Gregorio - } \\
\text { PG120317 }\end{array}$ \\
\hline & H1940 (O-F-256515) & - & MN598140 & - & $\begin{array}{l}\text { Spain, Rioja, } \\
\text { Sorzano }\end{array}$ & 24.06 .2013 & $\begin{array}{l}\text { R. Martinez, } \\
\text { L. Ballester - } \\
\text { LB13062401 }\end{array}$ \\
\hline & H1942 (O-F-256516) & - & MN598141 & - & $\begin{array}{l}\text { Spain, Rioja, } \\
\text { Ventas Blancas }\end{array}$ & 29.04.2012 & $\begin{array}{l}\text { G. Munoz - } \\
\text { GM2507 }\end{array}$ \\
\hline & H1943 (O-F-256517) & - & MN598142 & - & $\begin{array}{l}\text { Spain, Rioja, } \\
\text { Almarza de } \\
\text { Cameros }\end{array}$ & 28.04 .2016 & $\begin{array}{l}\text { G. Munoz- } \\
\text { GM2920 }\end{array}$ \\
\hline & H2876 (TRH-12717) & - & MN598166 & - & $\begin{array}{l}\text { Spain, Balearic } \\
\text { Islands, Mallorca, } \\
\text { Lluch }\end{array}$ & 08.04 .1982 & L. Sivertsen \\
\hline
\end{tabular}


Table 1. (Continued).




Table 1. (Continued).

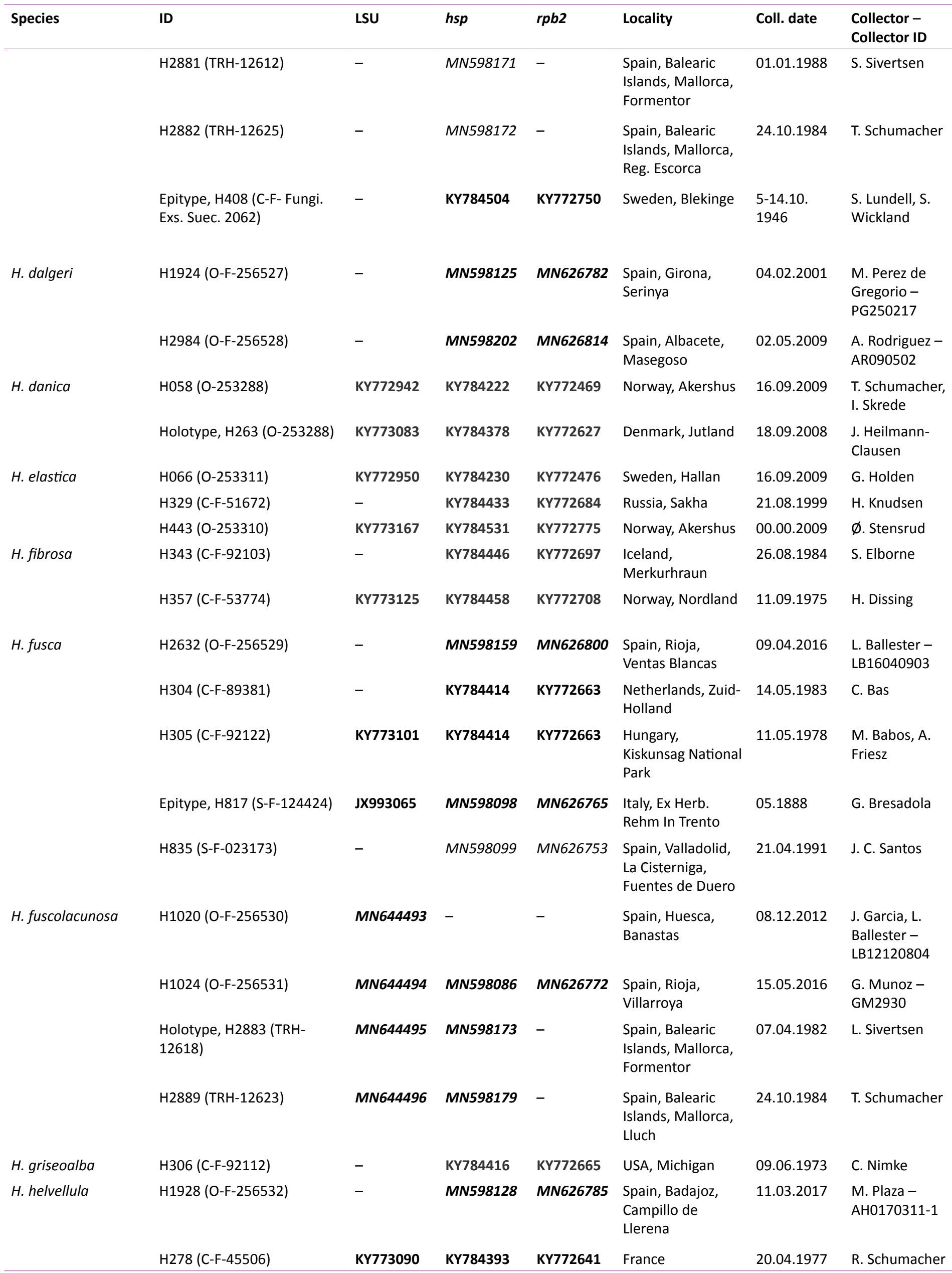


Table 1. (Continued).

\begin{tabular}{|c|c|c|c|c|c|c|c|}
\hline Species & ID & LSU & hsp & $r p b 2$ & Locality & Coll. date & $\begin{array}{l}\text { Collector - } \\
\text { Collector ID }\end{array}$ \\
\hline & Epitype, H308 (C-F-92128) & - & KY784418 & KY772667 & $\begin{array}{l}\text { Spain, Canary } \\
\text { Islands, Hierro, } \\
\text { toward Taibique }\end{array}$ & 07.01.1977 & $\begin{array}{l}\text { R. Korf, Fogel, } \\
\text { Hennebert, L. } \\
\text { Kohn }\end{array}$ \\
\hline & H309 (C-F-45469) & KY773103 & KY773103 & - & $\begin{array}{l}\text { France, Region des } \\
\text { Landes }\end{array}$ & 01.03.1981 & F. Candoussau \\
\hline & H523 (O-F-256534) & - & MN598085 & MN626760 & $\begin{array}{l}\text { Spain, Rioja, } \\
\text { Avellaneda }\end{array}$ & 14.04 .2007 & $\begin{array}{l}\text { R. Martinez - } \\
\text { RM321 }\end{array}$ \\
\hline & H525 (O-F-256535) & - & MN598093 & - & $\begin{array}{l}\text { Spain, Rioja, } \\
\text { Entrena }\end{array}$ & 21.02 .2015 & $\begin{array}{l}\text { R. Martinez, } \\
\text { L. Ballester - } \\
\text { LB15022101 }\end{array}$ \\
\hline \multirow[t]{2}{*}{ H. hispanica } & H1023 (O-F-256536) & MN644504 & MN598112 & MN626771 & $\begin{array}{l}\text { Spain, Rioja, Santa } \\
\text { Lucia }\end{array}$ & 06.04 .2015 & $\begin{array}{l}\text { A. Melendez - } \\
\text { PIPE0833 }\end{array}$ \\
\hline & $\begin{array}{l}\text { Holotype, H1929 (O-F- } \\
\text { 256537) }\end{array}$ & - & MN598129 & MN626786 & $\begin{array}{l}\text { Spain, Rioja, } \\
\text { Ventosa }\end{array}$ & 11.03 .2017 & $\begin{array}{l}\text { L. Ballester - } \\
\text { LB17031103 }\end{array}$ \\
\hline \multirow[t]{2}{*}{ H. hypocrateriformis } & H275 (C-F-57126) & - & KY784390 & KY772638 & $\begin{array}{l}\text { Switzerland, } \\
\text { Graubünden }\end{array}$ & 07.09.1982 & H. Dissing \\
\hline & Epitype, H301 (C-F-85205) & - & KY784411 & KY772660 & Sweden, Uppland & 21.07.1948 & R. Molander \\
\hline H. iberica & H1016 (O-F-256538) & MN644597 & MN598108 & MN626767 & $\begin{array}{l}\text { Spain, Rioja, } \\
\text { Tudelilla }\end{array}$ & 03.04 .2016 & $\begin{array}{l}\text { G. Munoz- } \\
\text { GM2907 }\end{array}$ \\
\hline \multirow{2}{*}{ H. juniperi } & $\begin{array}{l}\text { Isotype, H2974 (ex MCVE } \\
20998 \text { (no 501/a)) }\end{array}$ & - & MN598195 & MN626808 & Italy, Lu, Viareggio & 16.03.1996 & $\begin{array}{l}\text { G. Baiano, } \\
\text { M. Filippa, D. } \\
\text { Garofoli }\end{array}$ \\
\hline & H415 (C-F-42193) & - & KY784510 & KY772754 & $\begin{array}{l}\text { Portugal, Minho, S } \\
\text { of S. Bartolomeu } \\
\text { do Mar, } \mathrm{N} \text { of } \\
\text { Esposende }\end{array}$ & 15.11 .2000 & $\begin{array}{l}\text { P. Boisen } \\
\text { Hansen }\end{array}$ \\
\hline \multirow[t]{2}{*}{ H. lactea } & $\begin{array}{l}\text { H262 (C-F Fungi. Exs. Suec. } \\
\text { 1355) }\end{array}$ & - & KY784377 & KY772626 & Sweden, Uppland & 25.07.1939 & N. Hylander \\
\hline & H374 (C-F-39379) & - & KY784473 & KY772722 & Denmark, Zealand & 27.08.1961 & H. Dissing \\
\hline \multirow[t]{2}{*}{ H. lacunosa } & H153 (O-285214) & KY773002 & KY784285 & KY772536 & $\begin{array}{l}\text { Norway, Sør- } \\
\text { Trøndelag }\end{array}$ & 10.06 .2007 & $\begin{array}{l}\text { R. Haugan - } \\
\text { S07415 }\end{array}$ \\
\hline & $\begin{array}{l}\text { Epitype, H407 (C-F Fungi } \\
\text { Exs. Suec. 2065) }\end{array}$ & KY773152 & KY784503 & KY772749 & $\begin{array}{l}\text { Sweden, Femsjö. } \\
\text { Skatåker }\end{array}$ & 04.10 .1948 & $\begin{array}{l}\text { S. Lundell, G. } \\
\text { Haglund }\end{array}$ \\
\hline H. leucophaea & H2628 (O-F-256545) & - & MN598155 & MN626797 & $\begin{array}{l}\text { Spain, Huesca, } \\
\text { Banastás }\end{array}$ & 08.12 .2012 & $\begin{array}{l}\text { J. Garcia, L. } \\
\text { Ballester - } \\
\text { LB12120805 }\end{array}$ \\
\hline
\end{tabular}


Table 1. (Continued).




Table 1. (Continued).

\begin{tabular}{|c|c|c|c|c|c|c|c|}
\hline Species & ID & LSU & hsp & $r p b 2$ & Locality & Coll. date & $\begin{array}{l}\text { Collector - } \\
\text { Collector ID }\end{array}$ \\
\hline & H2890 (TRH-12624) & - & MN598180 & - & $\begin{array}{l}\text { Spain, Balearic } \\
\text { Islands, Mallorca, } \\
\text { Lluch }\end{array}$ & 24.10 .1984 & W. Holm \\
\hline & H2891 (TRH-12627) & - & MN598181 & - & $\begin{array}{l}\text { Spain, Balearic } \\
\text { Islands, Mallorca, } \\
\text { Reg. Escorca }\end{array}$ & 24.10 .1984 & T. Schumacher \\
\hline & H401 (C-F-49767) & - & MN598089 & - & France, Avignon & 22.10 .1974 & H. Dissing \\
\hline \multirow[t]{3}{*}{ H. nigra } & Epitype, H063 (O-253345) & KY772947 & KY772947 & KY784227 & $\begin{array}{l}\text { Sweden, Hallan, } \\
\text { Halmstad }\end{array}$ & 16.09 .2009 & G. Holden \\
\hline & H1030 (O-F-256557) & - & KY784572 & KY772816 & $\begin{array}{l}\text { Spain, Bizkaia, } \\
\text { Urkiola }\end{array}$ & 19.10.2007 & $\begin{array}{l}\text { G. Munoz - } \\
\text { GM1085 }\end{array}$ \\
\hline & H2622 (O-F-256558) & MN644492 & MN598149 & MN626793 & $\begin{array}{l}\text { Spain, Navarra, } \\
\text { Suarbe }\end{array}$ & 07.10 .2017 & $\begin{array}{l}\text { C. Echavarri - } \\
\text { CE17100701 }\end{array}$ \\
\hline \multirow[t]{3}{*}{ H. pallescens } & H136 (0-220306) & KY772987 & KY784269 & KY772519 & $\begin{array}{l}\text { Norway, } \\
\text { Hordaland, Ulvik }\end{array}$ & 28.08 .2001 & G. Flatab $\varnothing$ \\
\hline & Epitype, H138 (O-66205) & KY772988 & KY784271 & KY772521 & $\begin{array}{l}\text { Norway, Møre og } \\
\text { Romsdal, Norddal }\end{array}$ & 29.08 .2003 & D. Holtan \\
\hline & H2630 (O-F-256559) & - & MN598157 & MN626798 & $\begin{array}{l}\text { Spain, Rioja, } \\
\text { Sojuela }\end{array}$ & 24.06 .2013 & $\begin{array}{l}\text { R. Martinez, } \\
\text { L. Ballester - } \\
\text { LB13062407 }\end{array}$ \\
\hline \multirow[t]{3}{*}{ H. palustris } & H019 (O-253358) & KY772914 & KY784196 & KY772440 & $\begin{array}{l}\text { Norway, Oppland, } \\
\text { Dovre }\end{array}$ & 07.08 .2009 & $\begin{array}{l}\text { T. Carlsen, T. } \\
\text { Schumacher, I. } \\
\text { Skrede }\end{array}$ \\
\hline & H043 (O-253359) & KY772933 & KY784214 & KY772458 & $\begin{array}{l}\text { Norway, Oppland, } \\
\text { Dovre }\end{array}$ & 07.08 .2009 & $\begin{array}{l}\text { T. Carlsen, T. } \\
\text { Schumacher, I. } \\
\text { Skrede }\end{array}$ \\
\hline & H350 (C-F-55330) & KY773123 & KY784451 & KY772702 & Finland, Kuusamo & 15.08 .1978 & H. Dissing \\
\hline \multirow[t]{3}{*}{ H. panormitana } & Epitype, H064 (0-253363) & KY772948 & KY784228 & KY772474 & $\begin{array}{l}\text { Sweden, Hallan, } \\
\text { Laholm }\end{array}$ & 16.09 .2009 & C. C. Mellberg \\
\hline & H145 (O-203499) & KY772994 & KY784278 & KY772528 & $\begin{array}{l}\text { Norway, Møre og } \\
\text { Romsdal, Stordal }\end{array}$ & 18.09.2005 & P. Larsen \\
\hline & H2627 (O-F-256563) & - & MN598154 & MN626796 & $\begin{array}{l}\text { Spain, Huesca, } \\
\text { Villanúa }\end{array}$ & 12.10 .2007 & $\begin{array}{l}\text { L. Ballester - } \\
\text { LB07101202 }\end{array}$ \\
\hline H. paraphysitorquata & Isotype, H271 (C-F-45305) & KY773085 & KY784386 & KY772634 & Spain, Teruel & 03.06 .1988 & Arroyo, Calon \\
\hline \multirow[t]{3}{*}{ H. pezizoides } & Epitype, H061 (0-253366) & KY772945 & KY784225 & KY772471 & $\begin{array}{l}\text { Sweden, Hallan, } \\
\text { Halmstad }\end{array}$ & 16.09 .2009 & S. Lund \\
\hline & H2636 (O-F-256564) & - & - & MN626756 & $\begin{array}{l}\text { Spain, Rioja, } \\
\text { Castroviejo }\end{array}$ & 09.08 .2014 & $\begin{array}{l}\text { R. Martinez - } \\
\text { RM2274 }\end{array}$ \\
\hline & H431 (C-F-52986) & KY773161 & KY784525 & KY772768 & $\begin{array}{l}\text { Denmark, N } \\
\text { Jutland }\end{array}$ & 06.10 .1997 & $\begin{array}{l}\text { M. } \\
\text { Christensen, K. } \\
\text { Hansen }\end{array}$ \\
\hline
\end{tabular}


Table 1. (Continued).

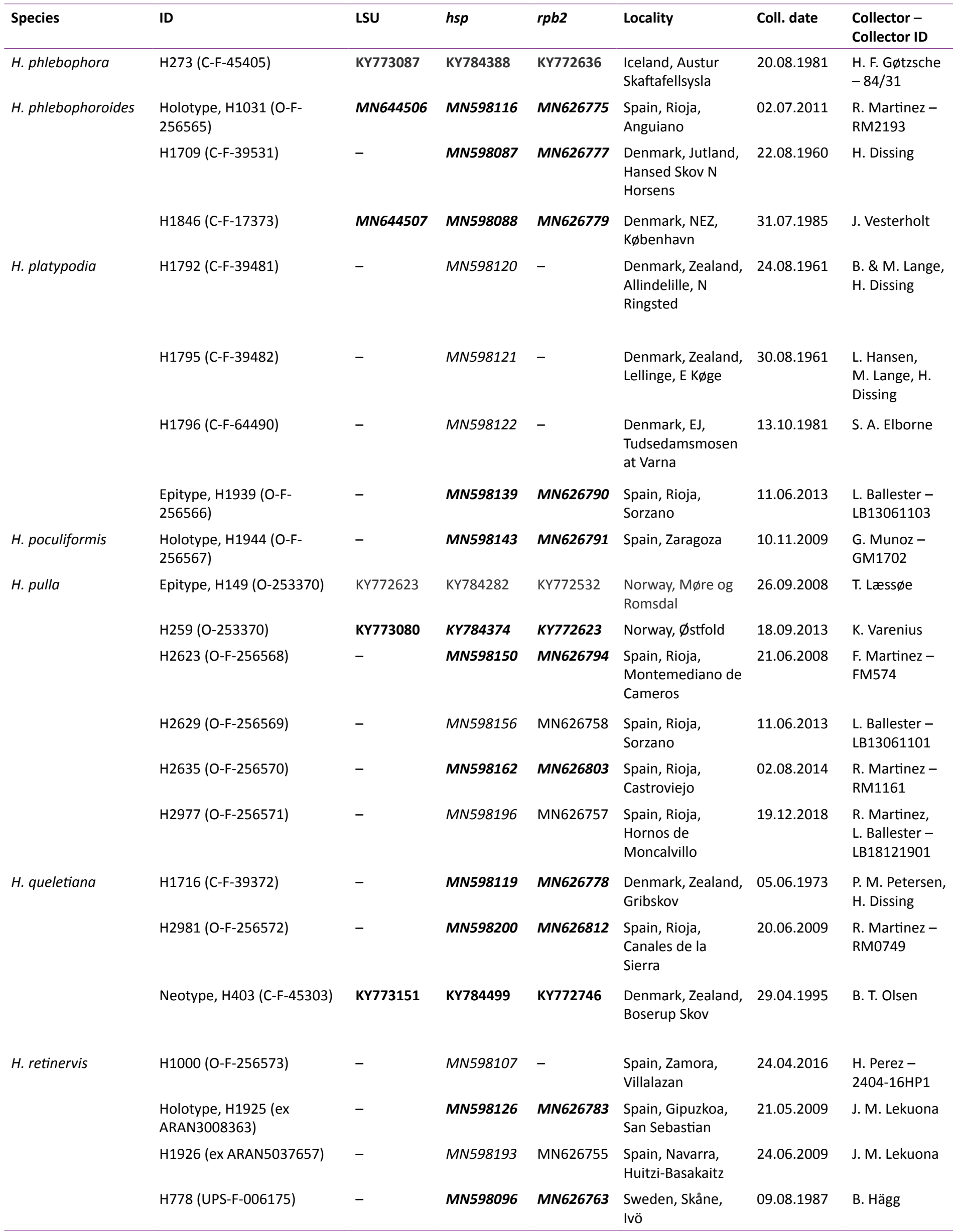


Table 1. (Continued).

\begin{tabular}{|c|c|c|c|c|c|c|c|}
\hline Species & ID & LSU & hsp & $r p b 2$ & Locality & Coll. date & $\begin{array}{l}\text { Collector - } \\
\text { Collector ID }\end{array}$ \\
\hline & H779 (UPS-F-122183) & - & MN598097 & MN626764 & $\begin{array}{l}\text { Sweden, Närke, } \\
\text { Hallsberg }\end{array}$ & 31.07 .1981 & S. Ryman \\
\hline \multirow[t]{6}{*}{ H. semiobruta } & H1922 (O-F-256574) & - & MN598123 & MN626780 & $\begin{array}{l}\text { Spain, Rioja, } \\
\text { Logrono, Pinar del } \\
\text { Gitano }\end{array}$ & 11.03 .2017 & $\begin{array}{l}\text { A. Ezquerro, } \\
\text { L. Ballester - } \\
\text { LB17031102 }\end{array}$ \\
\hline & H2901 (TRH-12614) & - & MN598190 & - & $\begin{array}{l}\text { Spain, Balearic } \\
\text { Islands, Mallorca, } \\
\text { Galilea }\end{array}$ & 27.12.1987 & S. Sivertsen \\
\hline & H522 (O-F-256575) & - & MN598091 & MN626759 & $\begin{array}{l}\text { Spain , Rioja, } \\
\text { Ventosa }\end{array}$ & 28.02 .2015 & $\begin{array}{l}\text { R. Martinez, } \\
\text { L. Ballester - } \\
\text { RM2302 }\end{array}$ \\
\hline & H526 (O-F-256577) & - & MN598094 & MN626761 & $\begin{array}{l}\text { Spain, Rioja, } \\
\text { Lardero }\end{array}$ & 21.03 .2015 & $\begin{array}{l}\text { R. Martinez, } \\
\text { L. Ballester - } \\
\text { LB15032101 }\end{array}$ \\
\hline & H529 (O-F-256578) & - & MN598095 & MN626762 & $\begin{array}{l}\text { Spain, Alava, } \\
\text { Laguardia }\end{array}$ & 12.03 .2016 & $\begin{array}{l}\text { A. Ezquerro - } \\
\text { AE16031201 }\end{array}$ \\
\hline & H1366 (C-F-45419) & - & MN598118 & MN626776 & $\begin{array}{l}\text { Sweden, Gotland, } \\
\text { at Skansudd S of } \\
\text { Fröjel }\end{array}$ & 28.05 .1968 & P. M. Petersen \\
\hline \multirow[t]{4}{*}{ H. solitaria } & H1923 (O-F-256579) & - & MN598124 & MN626781 & $\begin{array}{l}\text { Spain, Huesca, } \\
\text { Villanua }\end{array}$ & 23.05 .2016 & $\begin{array}{l}\text { J. Garcia, L. } \\
\text { Ballester - } \\
\text { LB16052302 }\end{array}$ \\
\hline & H1946 (O-F-256583) & - & MN598145 & - & $\begin{array}{l}\text { Spain, Rioja, } \\
\text { Tudelilla }\end{array}$ & 29.04 .2012 & $\begin{array}{l}\text { G. Munoz - } \\
\text { GM2506 }\end{array}$ \\
\hline & H2902 (TRH-12608) & - & MN598191 & - & $\begin{array}{l}\text { Spain, Balearic } \\
\text { Islands, Mallorca, } \\
\text { Escorca, Pollenza }\end{array}$ & 02.04 .1985 & $\begin{array}{l}\text { L \& S. } \\
\text { Sivertsen }\end{array}$ \\
\hline & H370 (C-F-45467) & - & KY784470 & $\kappa Y 772720$ & Spain, Valdepenas & 06.07.1975 & $\begin{array}{l}\text { Lundell, } \\
\text { Morand }\end{array}$ \\
\hline \multirow[t]{5}{*}{ H. sublicia } & H1932 (O-F-256584) & - & MN598132 & MN626789 & $\begin{array}{l}\text { Spain, Rioja, } \\
\text { Castroviejo }\end{array}$ & 09.07.2016 & $\begin{array}{l}\text { R. Martinez - } \\
\text { RM2390 }\end{array}$ \\
\hline & H1947 (O-F-256585) & - & MN598146 & - & $\begin{array}{l}\text { Spain, Asturias, } \\
\text { Covandonga }\end{array}$ & 22.07 .2011 & $\begin{array}{l}\text { G. Munoz- } \\
\text { GM2192 }\end{array}$ \\
\hline & H2625 (O-F-256586) & - & MN598152 & - & $\begin{array}{l}\text { Spain, Huesca, } \\
\text { Villanova }\end{array}$ & 01.08 .2006 & $\begin{array}{l}\text { R.Tena \& L. } \\
\text { Ballester - } \\
\text { LB06080101 }\end{array}$ \\
\hline & H2637 (O-F-256587) & - & MN598163 & MN626804 & $\begin{array}{l}\text { Spain, Rioja, Santa } \\
\text { Coloma }\end{array}$ & 18.09 .2014 & $\begin{array}{l}\text { R. Martinez - } \\
\text { RM2286 }\end{array}$ \\
\hline & Epitype, H417 (C-F-39823) & KY773155 & KY784512 & KY772756 & $\begin{array}{l}\text { Denmark, Zealand, } \\
\text { Sorø }\end{array}$ & 02.10 .1993 & K. Hansen \\
\hline H. sulcata & H1027 (O-F-256588) & MN644505 & MN598115 & MN626774 & $\begin{array}{l}\text { Spain, Rioja, } \\
\text { Clavijo }\end{array}$ & 22.11 .2013 & $\begin{array}{l}\text { R. Martinez - } \\
\text { RM2238 }\end{array}$ \\
\hline
\end{tabular}


Table 1. (Continued).

\begin{tabular}{|c|c|c|c|c|c|c|c|}
\hline Species & ID & LSU & hsp & $r p b 2$ & Locality & Coll. date & $\begin{array}{l}\text { Collector - } \\
\text { Collector ID }\end{array}$ \\
\hline & Epitype, H152 (O-69282) & KY773001 & KY784284 & KY772535 & Norway, Oslo & 13.10.2006 & $\begin{array}{l}\text { O. Smith, A.-S. } \\
\text { Karlsson }\end{array}$ \\
\hline & H2979 (O-F-256589) & - & MN598198 & MN626810 & $\begin{array}{l}\text { Spain, Huesca, } \\
\text { Barbaruens }\end{array}$ & 28.09.2018 & $\begin{array}{l}\text { R. Martinez, } \\
\text { L. Ballester - } \\
\text { LB18092809 }\end{array}$ \\
\hline & H2980 (O-F-256590) & - & MN598199 & MN626811 & $\begin{array}{l}\text { Spain, Huesca, } \\
\text { Barbaruens }\end{array}$ & 28.09.2018 & $\begin{array}{l}\text { F. Pancorbo, } \\
\text { L. Ballester - } \\
\text { LB18092802 }\end{array}$ \\
\hline H. terricola & $\begin{array}{l}\text { Holotype, H2978 (O-F- } \\
\text { 256562) }\end{array}$ & - & MN598197 & MN626809 & $\begin{array}{l}\text { Spain, Huesca, } \\
\text { Cerler }\end{array}$ & 28.09.2018 & $\begin{array}{l}\text { F. Cervera, L. } \\
\text { Ballester - } \\
\text { LB18092810 }\end{array}$ \\
\hline
\end{tabular}

spores from one individual were measured and the minimum mean - maximum values are reported.

DNA was extracted from all specimens using the E.Z.N.A. ${ }^{\circledR} \mathrm{HP}$ Fungal DNA Kit (Omega Biotek D3195), following the slightly modified procedure from Skrede et al. (2017).

The three genetic markers heat shock protein 90 (hsp), RNA polymerase II second largest subunit ( $r p b 2$ ) and nuclear ribosomal large subunit DNA (LSU) were amplified using PuReTaq Ready-ToGo PCR Beads (GEhealthcare, Waukesha, WI), and purified with ExoSAP-IT (GEhealthcare, Waukesha, WI). For primer sequences, detailed PCR conditions, and sequencing techniques, see the procedure in Skrede et al. (2017). In addition to the sequences produced in the present study, a representative selection of sequences from Helvella species from other geographic regions were downloaded from GenBank and included for reference. Information on specimens studied and all new and retrieved sequences with accession numbers in GenBank is given in Table 1. The sequences were automatically aligned using the MUSCLE v. 3.8.425 (Edgar 2004) plugin in Geneious Prime 2019.0.4 (Biomatters, Auckland). Alignments of each marker were analysed individually by the Maximum Likelihood (ML) method implemented in RAxML v. 8.2.11 (Stamatakis 2006), using the GTRCAT approximation. The best ML tree from the analysis of a concatenated, partitioned alignment of three genetic markers is presented in Fig. 1. In this concatenated dataset, we allowed for the inclusion of some missing data by permitting individuals with only LSU, rpb2 and $h s p, h s p$ and LSU or rpb2 and LSU. Bootstrap analyses using 1000 pseudoreplications were included in all $\mathrm{ML}$ analyses. The concatenated alignment is available in Dryad (http://datadryad.org).

The ML analyses were the basis for species delimitation. A simplified genealogical concordance phylogenetic species recognition (Avise \& Ball 1990, Taylor et al. 2000, Dettman et al. 2003) was used, where terminal clades with bootstrap support $>70 \%$ from two or more genetic markers were considered to be species. Some intraspecific variation was allowed.

\section{RESULTS}

\section{Phylogeny}

A total of 118 hsp, 69 rpb2 and 17 LSU sequences were produced and submitted to GenBank. The final concatenated alignment was 1163 bp (279, 346, 538 bp for $h s p, r p b 2$ and LSU, respectively). The ML phylogenetic tree has high support on most nodes toward the tips of the branches and is highly discriminating among species (Fig. 1). Although the basal nodes are mainly not supported, most of the main lineages and clades in Skrede et al. (2017) were retrieved.

The resulting $\mathrm{ML}$ analyses demonstrated the presence of 27 Spanish species. Spanish representatives of four additional species, i.e. H. calycina, H. crispa, H. macropus and H. pezizoides were not included in the concatenated dataset, since only $h s p$ sequences were obtained (Table 1). Thus, 31 Spanish species are included in the present survey. The sequenced specimens from our samples are assigned to major lineages and clades across the genus Helvella. Nine independent lineages are defined as new species, i.e. $H$. phlebophoroides, $H$. hispanica, $H$. neopallescens, $H$. terricola, $H$. fuscolacunosa, $H$. iberica, $H$. inexpectata, $H$. retinervis and $H$. poculiformis, of which seven are nested in the /lacunosa clade (indicated as A in Fig. 1). The other two new species are found elsewhere in the phylogeny, one as a sister species to the /lacunosa clade (i.e. H. retinervis) and one as sister to $H$. sublicia (i.e. H. poculiformis).

\section{Taxonomy}

Dissingia leucomelaena (Pers.) K. Hansen \& X.H. Wang, Persoonia 42: 198. 2019. Fig. 2A.

Basionym: Peziza leucomelas Pers., Mycol. Eur. 1: 219. 1822. Synonym: Helvella leucomelaena (Pers.) Nannf., in Lundell \& Nannfeldt, Fungi exs. Suec. Fasc. 19-20: 21, no. 952. 1941. See Skrede et al. (2017) for additional synonyms.

Illustration: Dissing (1966b: fig. 8, as H. leucomelaena).

Apothecium stipitate-cupulate, cup 2-8 cm broad, $1-5 \mathrm{~cm}$ deep, with crenate margin and expanded into irregular lobes, hymenium greyish brown to dark brownish black, often with a violaceus tinge, receptacle surface pubescent, upper part whitish to dark greyish brown, below gradually paler to yellowish white. Stipe short, $0.5-2 \mathrm{~cm}$ high, $0.6-1 \mathrm{~cm}$ broad, with blunt irregular ribs and grooves, with internal chambers. Medullary excipulum thick, of dense textura intricata, hyphae 3-5 $\mu \mathrm{m}$ broad. Outer excipulum of textura angularis, cells 10-24 $\mu \mathrm{m}$, interspersed with some narrow hyphae of prismatic cells, outermost cells in rows turning out perpendicular to receptacle surface giving rise to tufts of fascicled hyphae consisting of club-shaped cells. Asci aporhynchous, 320-380 × 12-14 $\mu \mathrm{m}$. Ascospores ellipsoid, 19.4-21.6-24.0 × 10.6-12.1-13.0 $\mu \mathrm{m}$. Paraphyses brownish, 4 $-5 \mu \mathrm{m}$ broad below, clavately enlarged to $7-11 \mu \mathrm{m}$ at the tips. 
Specimens examined/sequenced: See Table 1.

Notes: This short-stipitate deeply cupulate species was recently re-combined in the new segregate genus Dissingia (Hansen et al. 2019), a genus molecularly and morphologically segregated from Helvella s. s. based on phylogenetic evidence (paraphyly) and asci that arise from simple septa. The often semi-immersed growth habit, with the whitish stipe buried in the soil, characterises the species.

Helvella acetabulum (L.) Quel., Hymenomycetes, Fasc. Suppl. (Alençon): 102. 1874. Fig. 2B, C.

Basionym: Peziza acetabulum L., Sp. PI. 2: 1181. 1753; Fr., Syst. Mycol. 2: 44. 1822

Synonyms: See Skrede et al. (2017).

Illustration: Harmaja (1977b: figs 1-2).

Apothecium stipitate-cupulate, $2.5-10 \mathrm{~cm}$ broad, by $3-8 \mathrm{~cm}$ high, hymenium pale brown to medium brown, drying dark brown, receptacle concolourous or pale yellowish brown, subpubscent. Stipe $1.5-7.5 \mathrm{~cm}$ high, $1.5-5 \mathrm{~cm}$ broad, broad above and narrowing towards the base, hollow inside, outside whitish to yellowish, with 5 to 7 prominent, mostly double-edged sharp ribs branching upwards to the attachment point about half way to the apothecial margin. Medullary excipulum of textura intricata, hyphae 4-8 $\mu \mathrm{m}$ broad, light brown-walled. Outer excipulum of textura angularis to textura prismatica, individual cells 10-25 $\mu \mathrm{m}$ diam, outermost cells prismatic, hyaline, 5-15 $\times 4-8 \mu \mathrm{m}$, arranged in rows that turn out perpendicular to receptacle surface. Asci pleurorhynchous, 310-380 × 13-16 $\mu \mathrm{m}$. Ascospores ellipsoid, uniguttulate, 15.5-17.4-19.2 × 10.5-11.4$13.2 \mu \mathrm{m}$. Paraphyses 3-5 $\mu \mathrm{m}$ below, brownish along their whole length, slightly enlarged at the clavate tips.

\section{Specimens examined/sequenced: See Table 1.}

Note: The Spanish collections are morphologically and molecularly identical to specimens recorded from Northern and Central Europe (cf. Skrede et al. 2017).

Helvella atra König in Oeder, Flora Danica 3 (9): 7. 1770. - nom. sanct. Fig. 3C.

Synonym: Leptopodia atra (König in Oeder) Boud., Icon. Mycol., liste prélim.: 2. 1904.

See Skrede et al. (2017) for additional synonyms.

Misapplied name: Helvella atra Holmsk., Beata ruris otia Fungis Danicis impensa 2: 47. 1799.

Illustrations: Oeder (1770: pl. 534, fig. 1), Boudier (1906: $\mathrm{n}^{\circ} .121$, pl. 228, as H. lacunosa, Filippa \& Baiano (2011: figs 9-11, as H. lacunosa).

Apothecium stipitate-capitate, saddle-shaped or irregularly lobed, 1-4 cm broad, 3-12 cm high, cap margin adnate and attached to stipe at 3 to 4 points, hymenium blackish with a dark violet brown tinge, even or wrinkled, receptacle surface greyish brown to black, smooth, with inconspicuous ribs on outer surface. Stipe $0.5-2.5 \mathrm{~cm}$ broad, naked, greyish brown to black, paler towards base, hollow and chambered inside, outside with 4 to 7 sharp and partly double-edged prominent ribs attached to the reflexed apothecial margin at 3 to 4 points, between ribs with deep grooves and lacunae ('holes'). Medullary excipulum of textura intricata, hyphae 3-5 mm broad. Outer excipulum of textura angularis, cells $8-15 \mu \mathrm{m}$ in diam, hyaline, outermost cells club-shaped, 10-30 × 5-15 $\mu \mathrm{m}$. Asci pleurorhynchous, 260-10 $\times$ 14-18 um. Ascospores ellipsoid, 15.5-17.1-18.5 × 10-11.3-12.5 $\mu \mathrm{m}$. Paraphyses subhyaline to light brown, 3-4 $\mu \mathrm{m}$ broad below, increasingly brown towards the $6-8 \mu \mathrm{m}$ broad clavate tips.

Specimens examined/sequenced: See Table 1.

Notes: An account of the nomenclatural history of this mediumsize greyish black species of the $H$. lacunosa morpho-species complex was given by Filippa \& Baiano (2011) and Skrede et al. (2017). Helvella atra is apparently less common in Southern compared to Northern Europe.

Helvella calycina Skrede et al., Persoonia 39: 221. 2017. Fig. 2D-F.

Basionym: Boletus calyciformis Battara, Fungorum Arimin.: 25. 1759; Fr., Syst. Mycol. 2: 45. 1822.

Synonyms: See Skrede et al. (2017).

Illustration: Dissing (1966b: fig. 16, as H. costifera).

Apothecium short-stipitate, at first cupulate, then expanded and irregularly folded, $2-7.5 \mathrm{~cm}$ broad, $1.5-4.5 \mathrm{~cm}$ high; hymenium brownish, receptacle surface greyish brown, pubescent to furfuraceous; stipe with 5 to 8 prominent, bluntedged, yellowish-white ribs dichotomously branched when extending onto receptacle surface, not reaching the margin in fully developed specimens, receptacle with concentric, parallel connections between ribs, making the surface somewhat wrinkled. Medullary excipulum of hyaline textura intricata, hyphae 3-5 $\mu \mathrm{m}$ broad. Outer excipulum of textura prismatica to textura angularis, outermost cells brown-walled. Asci pleurorhynchous, cylindrical, 240-280 × 11-14 $\mu \mathrm{m}$. Ascospores ellipsoid, uniguttulate, 14.5-16.2-17.6 × 9.5-10.8-12.0 $\mu \mathrm{m}$. Paraphyses $2.5-3.5 \mu \mathrm{m}$ broad below, straight, septate, gradually enlarged to 4-6 $\mu \mathrm{m}$ at the tips.

\section{Specimens examined/sequenced: See Table 1.}

Notes: The species was re-named and re-described in Skrede et al. (2017), based on a taxon originally described from Italy as Boletus calyciformis by Battara (1759). Helvella calycina seems common throughout Europe, and was recently also reported from China (Wang et al. 2019). The North European and Spanish specimens are molecularly identical and diverge genetically from its sister species $H$. costifera in one consistent $h s p$ and two rpb2 SNPs.

Helvella crispa (Scop.) Fr., Syst. Mycol. 2: 14. 1822. Fig. 4B. Basionym: Phallus crispus Scop., Fl. Carniol., ed. 2, 2: 475. 1772; Fr., Syst. Mycol. 2: 14. 1822.

Synonym: Helvella pallida Schaeff., Fung. Bavar. Palat. Nasc. 4: 112. 1774.

See Skrede et al. (2017) for additional synonyms.

Illustrations: Boudier (1909b: n. 490, pl. 225), Dissing (1966b: fig. 21).

Apothecium stipitate-capitate, $2-7 \mathrm{~cm}$ broad, irregularly bi- to tri-lobate, saddle-shaped, with inrolled, free margin, hymenium 


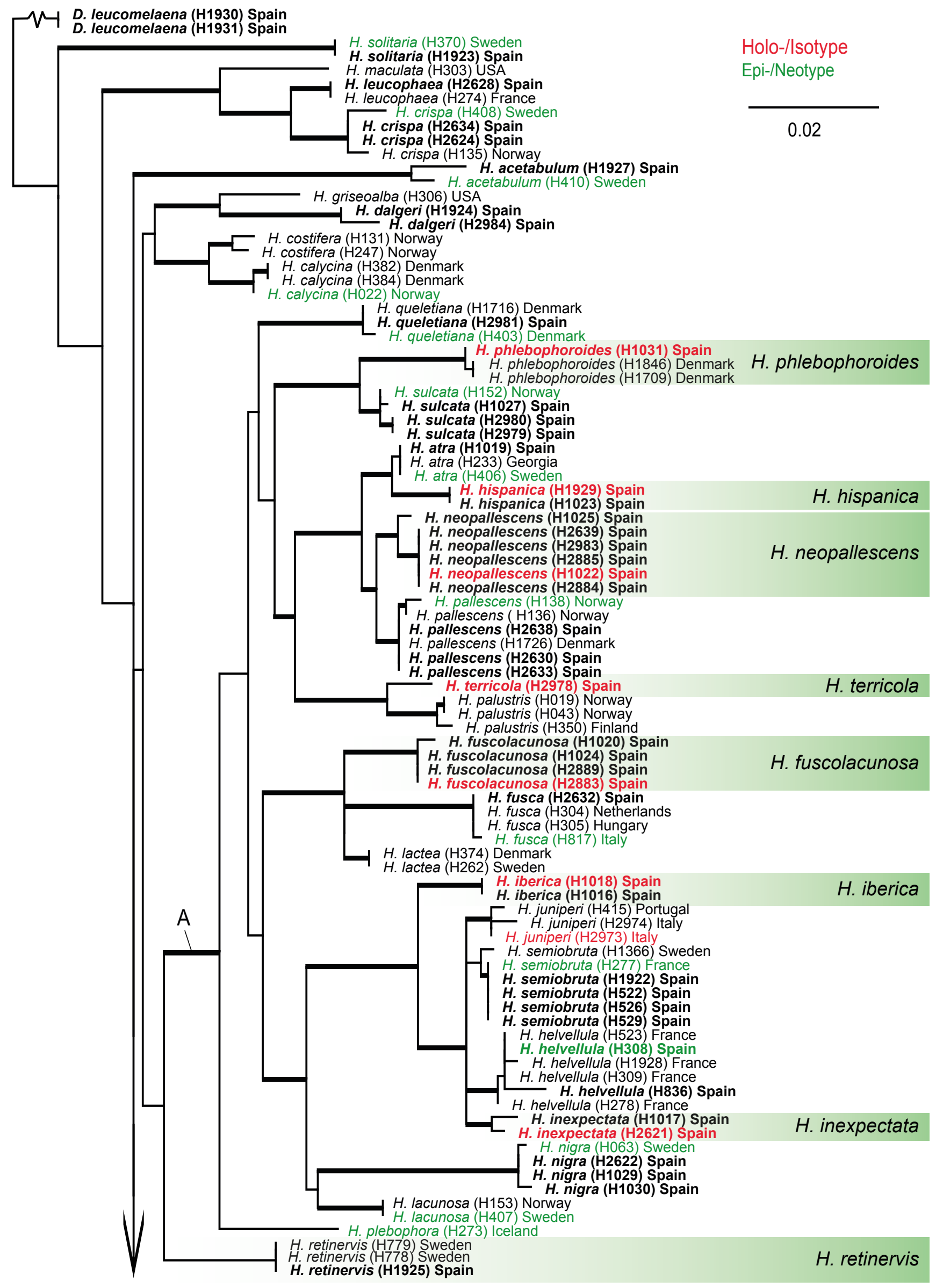

Fig. 1. Maximum likelihood tree of Spanish and other members of Helvella using parts of the RNA polymerase II second largest subunit (rpb2), heat shock protein 90 ( $h s p)$ and nuclear ribosomal large subunit DNA (LSU). Branches supported by ML bootstrap analyses (>70) are thickened. Dissingia leucomelaena is used as outgroup. Sequences from holo-/isotype (red) and epi-/neotype (green) are colour-coded. Green boxes indicate species described in the present study. Sequences from Spain are in bold. 


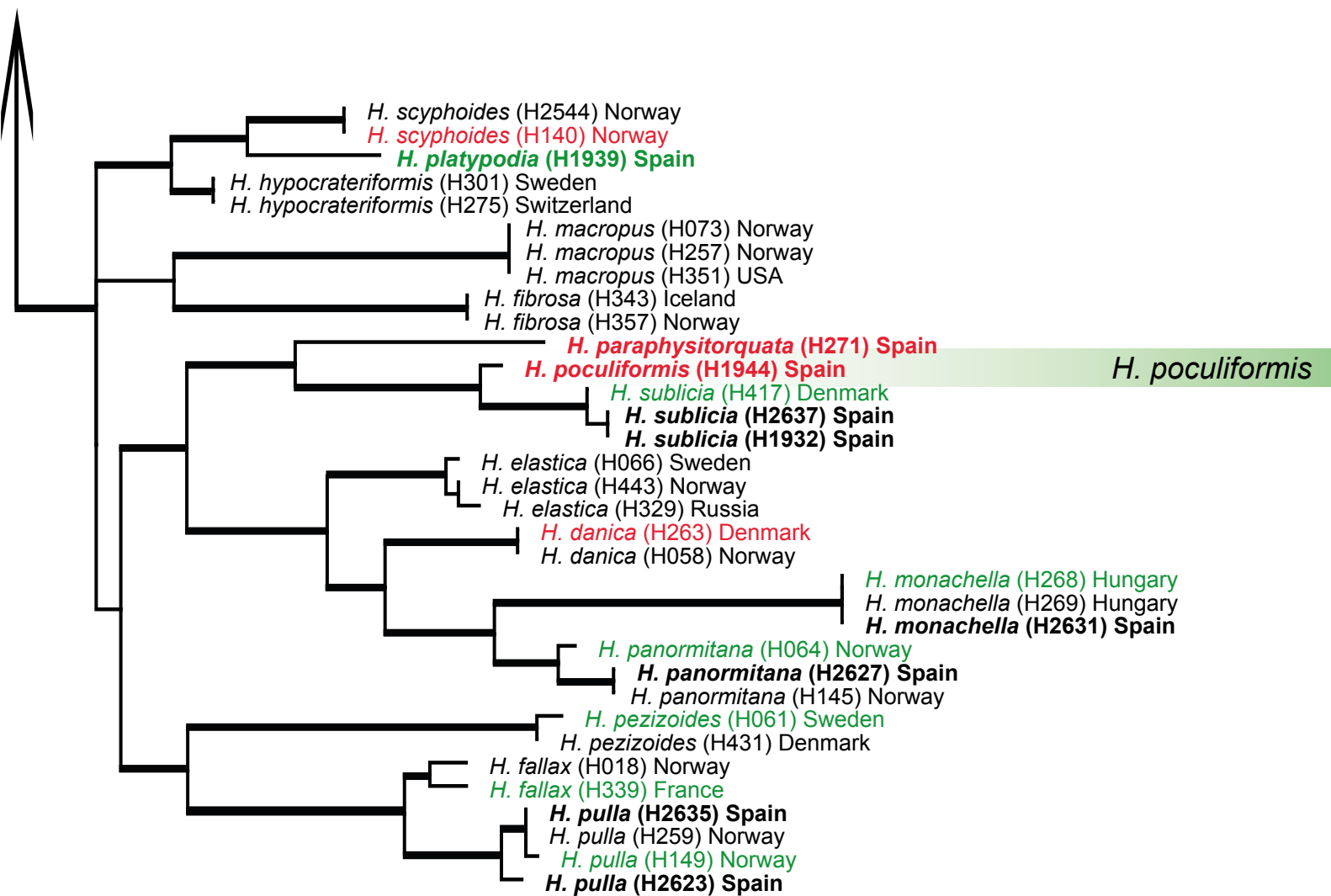

Fig. 1. (Continued).

white to light greyish white, drying yellowish to brownish, receptacle surface even, pubescent, pale to medium brown. Stipe prominent, $3-10 \mathrm{~cm}$ high, $1-3 \mathrm{~cm}$ broad, widest below, pure white when fresh, with densely set irregular longitudinal anastomosing ribs and dep grooves, hollow with longitudinal chambers inside. Medullary excipulum of textura intricata, hyphae 5-7 $\mu \mathrm{m}$ broad. Outer excipulum of textura angularis, cells irregular in shape and size, $12-25 \times 5-25 \mu \mathrm{m}$, outermost cells prismatic to club-shaped, arranged in fascicled rows forming tufts of hyphae, walls pale brown. Asci pleurorhynchous, 260$310 \times 12-16 \mu \mathrm{m}$. Ascospores ellipsoid, uniguttulate, 17.8-19.0$21.4 \times 10.8-11.9-12.6 \mu \mathrm{m}$. Paraphyses 3-4 $\mu \mathrm{m}$ below, slightly enlarged to 6-9 $\mu \mathrm{m}$ at the clavate tips.

Specimens examined/sequenced: See Table 1.

Notes: European specimens of $H$. crispa, including the Spanish specimens, are morphologically uniform, but molecularly variable, however, still constituting a single distinct species in our phylogeny (cf. Fig. 1).

Helvella dalgeri Donadini, Bull. Soc. linn. Provence 35: 136. 1985 [1984]. Fig. 2G, H.

Basionym: Acetabula barlae Boud., Hist. Class. Discom. Eur.: 40. 1907.

non Helvella barlae Boud. \& Pat., J. Bot., Paris 2: 445. 1888.

Illustration: Boudier (1908b): $\mathrm{n}^{\circ} .349$, pl. 245 (as Acetabula barlae).

Apothecium regularly short-stipitate cupulate, cup $3-5 \mathrm{~cm}$ broad, stipe $0.5-1.5 \mathrm{~cm}$ high, $0.7-1.5 \mathrm{~cm}$ broad, hymenium black, receptacle dark greyish black, with conspicuous, delicate white ribs extending from the stipe onto the receptacle; ribs on stipe and receptacle high and prominent, sharp-edged, branching, attachment points of ribs in periphery at the mid part of the receptacle surface. Medullary excipulum of compact textura intricata, hyphae multiseptate, 4-7 $\mu \mathrm{m}$ broad. Outer excipulum of textura angularis, cells $20-35 \times 10-20 \mu \mathrm{m}$, outermost cells cylindrical to drum-shaped forming dense rows of cells turning out perpendicular to receptacle surface. Asci cylindrical, pleurorhynchous, $280-340 \times 14-18 \mu \mathrm{m}$, with a long, flexuous, spore-free lower part. Ascospores ellipsoid, 18.2-19.2-20.5 $\times$ 9.4-10.1-11.4 $\mu \mathrm{m}$, with one large internal guttule. Paraphyses 3-4 $\mu \mathrm{m}$ broad below, enlarged to a clavate apical cell segment 20-30 $\mu \mathrm{m}$ long, by 5-7 $\mu \mathrm{m}$ broad.

Specimens examined/sequenced: See Table 1.

Notes: This relatively large, greyish black, short-stipitate species was described as Acetabula barlae by Boudier (1908b). Since the earlier name Helvella barlae Boud. \& Pat. (1888) exists, Donadini (1985) proposed the new name H. dalgeri for this South European species. The species was misinterpreted by Skrede et al. (2017) who, based on Boudier's plate and description (Boudier 1908b), placed Acetabula barlae in synonymy with Helvella arctoalpina Harmaja. The prominent white ribs on cup and stipe, which contrast with the dark-coloured receptacle surface, characterise the gross morphology of the species. In our phylogeny (Fig. 1) Helvella dalgeri is nested with $H$. griseoalba in a highly supported clade sister to the /costifera lineage in our phylogeny (cf. Fig. 1). A hypogeous Helvella specimen from Masegoso (Albacete) was shown molecularly identical to H. dalgeri (cf. Fig. 2G and Table 1).

Helvella fusca Gillet, Champ. Fr., Discom. 1: 9. 1879. Fig. 5B. Synonyms: See Skrede et al. (2017). 
Illustrations: Gillet (1879: pl. 4), Dissing (1966b: fig. 23), Landeros \& Korf (2012: figs 1-4).

Apothecium stipitate-capitate, $1.8-3.5 \mathrm{~cm}$ broad, $0.7-4.5 \mathrm{~cm}$ high, irregularly bi- to tri- to tetralobate, saddle-shaped, with adnate, partly fused margin, hymenium light to medium to dark brown when fresh, drying brownish black, receptacle greyish white to pale brown, sub-pubescent, with low, anastomosing densely packed ribs on the receptacle surface. Stipe white to yellowish brown, 3-7 cm high, 1-2.5 cm broad, with longitudinal
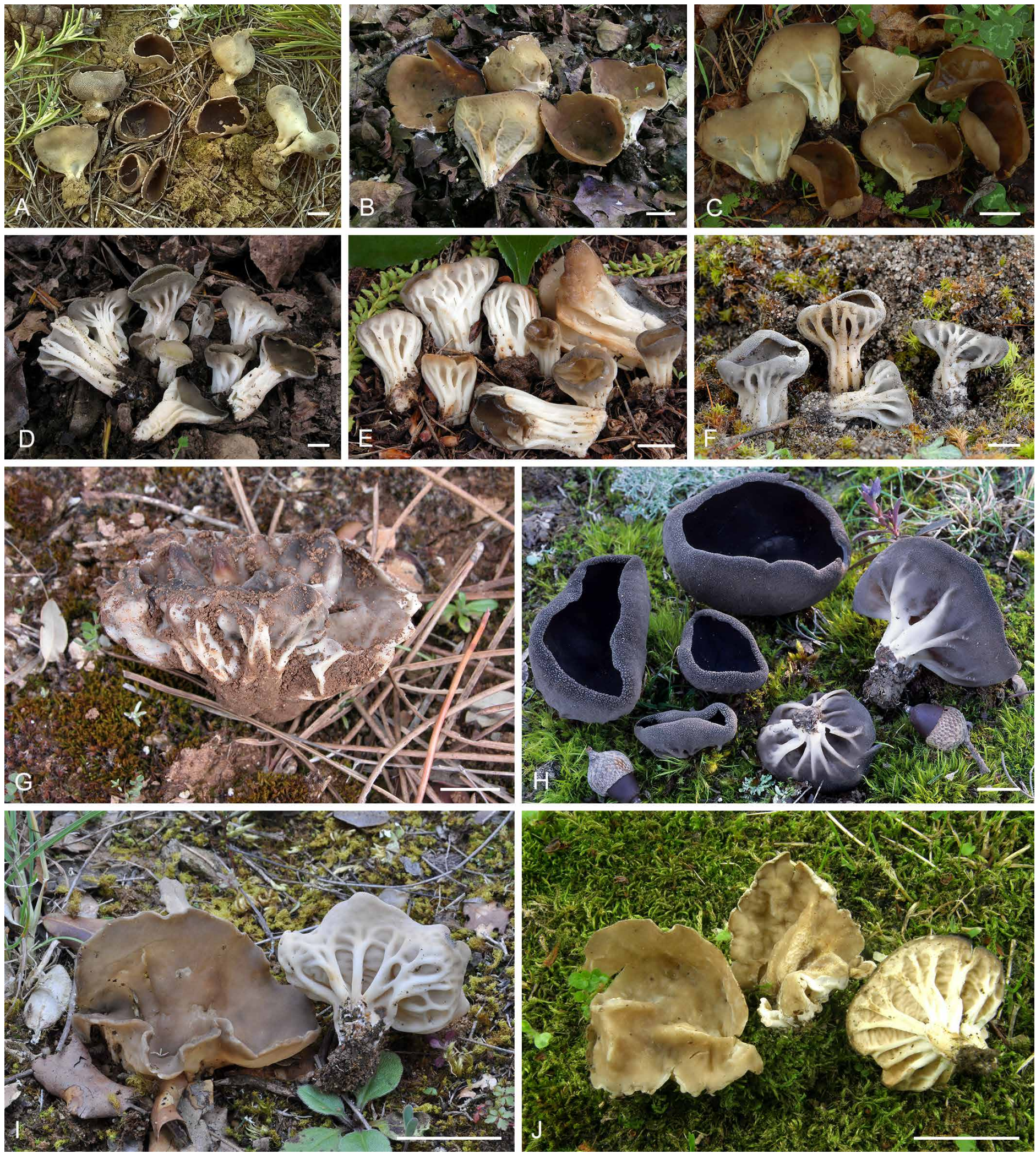

Fig. 2. Photographs of apothecia in their natural habitat. A. Dissingia leucomelaena AEA0010 [H1930]. B. Helvella acetabulum LB13062401 [H1940]. C. H. acetabulum GM2507 [H1942]. D. H. calycina GM1504 [H848]. E. H. calycina RM2338 [H845]. F. H. calycina FB160514 [H849]. G. H. dalgeri AR090502 [H2984]. H. H. dalgeri PG250217 [H1924]. I. H. retinervis 2404-16HP1 [H1000]. J. H. retinervis ARAN3008363 [H1925]. Scale bars $=1 \mathrm{~cm}$. All photographs taken by the collectors (confer Table 1 ). 
anastomosing ribs and deep, partly lacunose furrows. Medullary excipulum of loosely interwoven textura intricata, hyphae 3-8 $\mu \mathrm{m}$ broad, hyaline. Outer excipulum of textura angularis to textura prismatica, brownish, outermost cells in rows perpendicular to receptacle surface, cells cylindrical to club-shaped, partly in fewcelled fascicles (tufts). Asci pleurorhynchous, 260-320 × 14-16 $\mu \mathrm{m}$. Ascospores uniguttulate, 17.4-18.7-20.8 × 11.0-12.1-13.2 $\mu \mathrm{m}$. Paraphyses 3-4 $\mu \mathrm{m}$ broad below, with yellowish brown content, enlarged to $5-8 \mu \mathrm{m}$ at the clavate tips.

Specimens examined/sequenced: See Table 1.
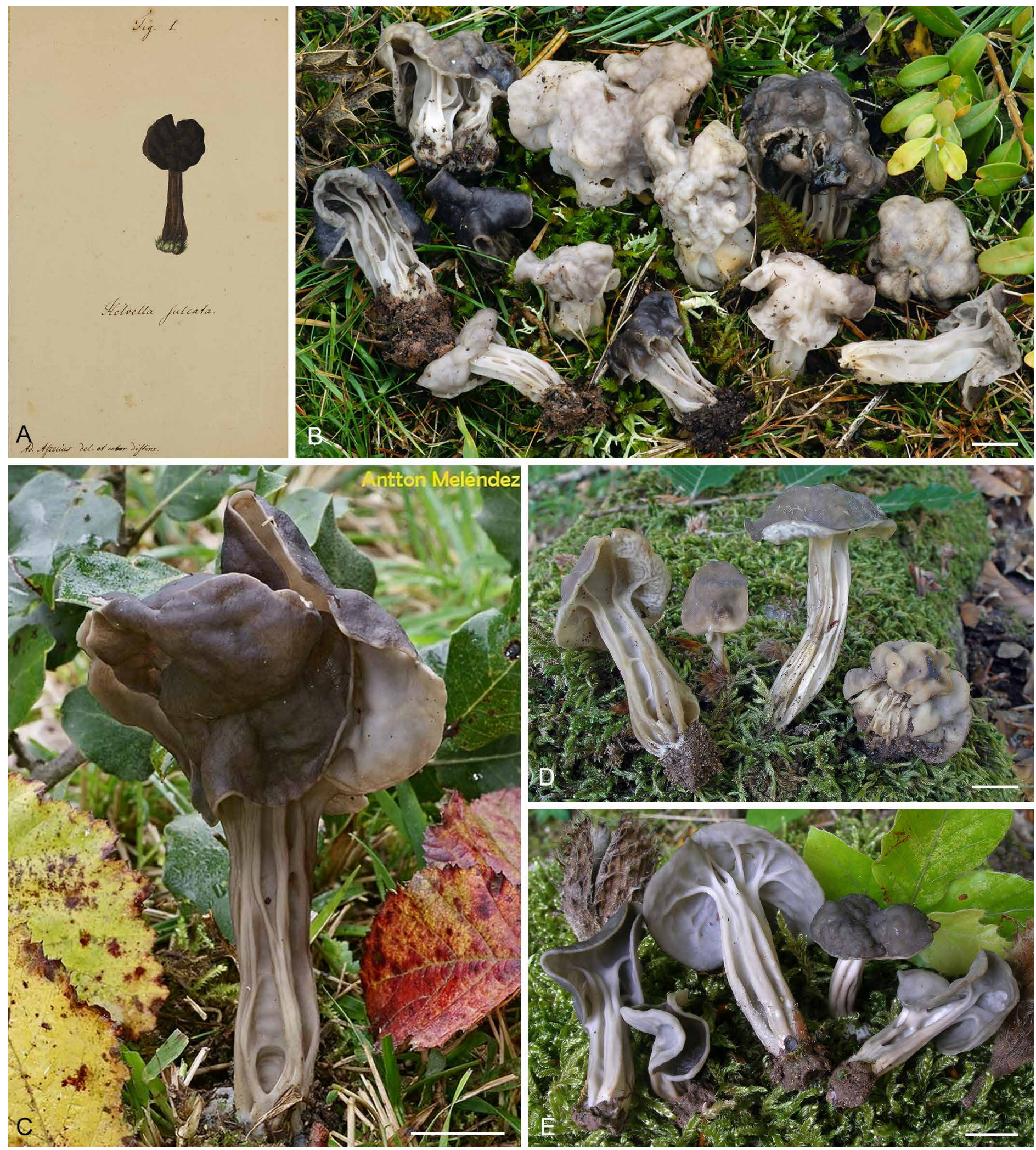

Fig. 3. Photographs of fresh apothecia and illustrations A. Authentic illustration of Helvella sulcata deposited in the fungarium of Uppsala (UPS), photograph taken by Åsa Kruys. B. H. sulcata RM2238 [H1027]. C. H. atra PIPE0966 [H1019]. D. H. queletiana RM0749 [H2981]. E. H. phlebophoroides RM2193 [H1031]. Scale bars $=1 \mathrm{~cm}$. Photographs B, C, D and E are taken by the collectors (confer Table 1). 



Fig. 4. Photographs of apothecia in their natural habitat. A. Helvella leucophaea LB121208 [H2628]. B. H. crispa LB07101201 [H2626]. C. H. nigra GM1085 [H1030]. D. H. juniperi MCVE 20997 [H2973]. Scale bars $=1 \mathrm{~cm}$. All photographs taken by the collectors (confer Table 1).

Notes: Helvella fusca is a spring and early summer occurring species characterised by a stipitate saddle-shaped apothecium with brown hymenium and a white, lacunose stipe with delicate anastomosing ribs extending onto the receptacle surface. Helvella fusca occurs in association with Populus and is likely to form ectomycorrhiza with this host. See Notes of $H$. fuscolacuonsa for information on how to distinguish $H$. fusca from the morphologically similar species $H$. fuscolacuosa.

Helvella fuscolacunosa Skrede \& T. Schumach. sp. nov. MycoBank MB834620. - Fig. 5A.

Etymology: Pertaining to the dark brown colour tinged with greyish and blackish (adj. fuscous) of the hymenium in combination with the ribbed, lacunose stipe.

Typus: Spain, Balearic Islands, Mallorca, Formentor, 7 Apr. 1982, S. Sivertsen (holotype TRH-12618).

Apothecium stipitate-capitate, $2.5-4.2 \mathrm{~cm}$ broad; irregularly saddle-shaped, trilobate, deflexed, that may mask its general shape; margin involute and wavy. Hymenium grey-brown to almost black, surface with \pm bulges; receptacle pale grey, subpubescent, occasionally with inconspicuous veins. Stipe whitish, hollow, with internal chambers, up to $5 \mathrm{~cm}$ high and $2 \mathrm{~cm}$ broad, sub-pubescent, with 5 to 8 partly anastomosing, sharp ribs and deep grooves and a few lacunae between, ribs continuing onto the receptacle surface. Medullary excipulum of densely packed textura intricata, hyphae 3-7 $\mu \mathrm{m}$ broad, light brown-walled. Outer excipulum of textura angularis with some interwoven hyphae between, cells 7-30 × 5-20 $\mu \mathrm{m}$, outermost cells cylindrical to club-shaped in rows terminating in a subcapitate up to $45 \mu \mathrm{m}$ long end cell. Asci cylindrical, pleurorhynchous, 270-300 × 13-17 $\mu \mathrm{m}$, ascospores often transversely arranged in young asci. Ascospores broadly ellipsoid, uniguttulate, 15.6$\underline{16.4}-18.8 \times 11.0-11.8-12.5 \mu \mathrm{m}$. Paraphyses 3-4 $\mu \mathrm{m}$ broad below, straight, enlarged to $6-8 \mu \mathrm{m}$ at the clavate tips.

Specimens examined/sequenced: See Table 1.

Notes: Helvella fuscolacunosa shares stature and hymenium colour with $H$. fusca and $H$. neopallescens. However, while the stipe is interspersed with some lacunae ("holes") in $H$. fuscolacunosa and $H$. fusca, these are lacking in $H$. neopallescens. Microanatomically, the ascospores in $H$. fuscolacunosa are smaller and broader than in $H$. fusca and $H$. neopallescens. Molecularly, $H$. fuscolacunosa deviates consistently in four $h s p$, three $r p b 2$ and 18 LSU substitutions from $H$. fusca, and in nine hsp, seven rpb2 and 25 LSU substitutions from $H$. neopallescens. 

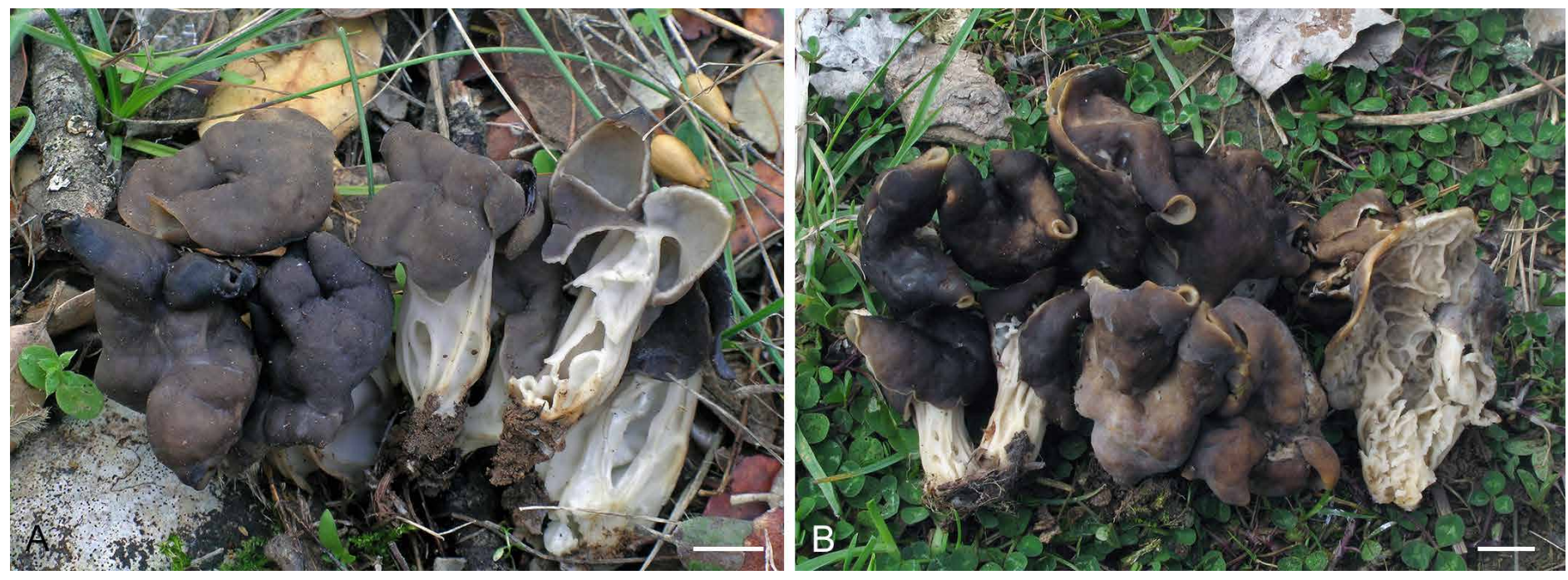

Fig. 5. Photographs of apothecia in their natural habitat. A. Helvella fuscolacunosa LB12120804 [H1020]. B. H. fusca LB160409 [H2632]. Scale bars = $1 \mathrm{~cm}$. Both photographs taken by the collectors (confer Table 1).

Helvella helvellula (Durieu) Dissing, Rev. Mycol. 31: 204. 1966. Fig. 6E, F.

Basionym: Peziza helvellula Durieu, Expl. Sci. Algerie 1: t. 27, f. 11. 1849.

Synonyms: See Skrede et al. (2017).

Illustrations: Durieu (1849): t. 27, f. 11, as Peziza helvellula, Boudier (1908a): n. 346, pl. 247, as Acetabula clypeata), Caroti et al. (2007: pp. 33, 35, 41).

Apothecium subsessile to short-stipitate-cupulate, 1.2-2.5 $\mathrm{cm}$ broad; cupulate to irregular cupuliform to discoid, margin undulate and gently involute, hymenium black, receptacle surface furfuraceous, blackish, slightly sooty (fuliginous) towards the stipe. Stipe short, solid, cylindrical to flattened, $0.7-1.2 \mathrm{~cm}$ high, by $0.3-0.7 \mathrm{~cm}$ broad, somewhat thickened at the base, with 1 to 2 longitudinal grooves, at the top concolourous with the receptacle, paler towards the base which is almost always totally buried. Medullary excipulum of textura intricata, hyphae 3-5 $\mu \mathrm{m}$ broad. Outer excipulum of textura angularis, cells of uneven size, 10-25 $\mu \mathrm{m}$ broad, interspersed with some inflated, larger cells $20-45 \times 10-15 \mu \mathrm{m}$. terminating into cylindrical to club-shaped cells towards the surface. Asci pleurorhynchous, 320-390 × 16-20 $\mu \mathrm{m}$. Ascospores ellipsoid, obtuse, with one large and several small internal guttules, 21.8-24.0-27.3 $\times$ 12.8-13.8-15.4 $\mu \mathrm{m}$. Paraphyses 3-4 $\mu \mathrm{m}$ broad below, slightly enlarged to $5-8 \mu \mathrm{m}$ at the irregularly clavate tips.

Specimens examined/sequenced: See Table 1.

Notes: Helvella helvellula is a subsessile to short-stipitate black, cupulate species, described by Durieu (1849) based on a specimen in Herb. C Montagne (PC). Dissing (1966a) did not find any original specimen of this Mediterranean species in Montagne's Herbarium in Paris (PC). Caroti et al. (2007) later succeeded in finding an original specimen from Morocco collected by M. Roussel in 1836 and deposited in Montagne's herbarium in PC (see photograph on p. 41 in Caroti et al.). This specimen, which apparently is part of the original description of Durieu's species is probably too old to provide DNA for sequencing, thus the epitype selected by Skrede et al. (2017) from the Canary Islands is still in place to provide necessary information for a molecular identification of the species.

The Spanish collections are from acid soil, at altitudes from 500 to 1100 m. a.s.l., always associated with Cistus, i.e. Cistus albidus, C. salviifolius and C. laurifolius. Short-stipitate specimens (see Fig. 6F) may be confused with $\mathrm{H}$. semiobruta, which occurs in the same habitat, but, the apothecia in $H$. semiobruta are stipitate-capitate, with a bi- to trilobate convex cap and an elongate hollow stipe.

Helvella hispanica Skrede \& T. Schumach. sp. nov. MycoBank MB834621. Fig. 7C, D.

Etymology: Referring to its place of origin (in Spanish language).

Typus: Spain, Ventosa, 11 Mar. 2017, L. Ballester LB17031103 (holotype O-F-256537).

Apothecium stipitate-capitate, cap $2.5-4.5 \mathrm{~cm}$ broad, irregular saddle-shaped, adnate, margin generally free but attached to the stipe at 2 to 4 points, hymenium dark greyish black to black, even or wrinkled folded, receptacle paler, greyish, smooth, with branching, blunt ribs. Stipe cylindrical, hollow, $2-7 \mathrm{~cm}$ high, 2-4.5 cm broad, whitish to grey, with 3 to 7 longitudinal, prominent, partly double-edged blunt ribs and deep grooves, occasional with some elongate lacunae. Medullary excipulum of dense textura intricata, hyphae 3-6 $\mu \mathrm{m}$ broad. Outer excipulum of textura angularis to textura prismatica, brownish, angular cells 10-20 $\mu \mathrm{m}$ interspersed with prismatic cells in rows, 8-14 $\mu \mathrm{m}$ broad, turning out perpendicular to receptacle surface, outermost cells club-shaped. Asci pleurorhynchous, 260-310 $\times$ 12-16 $\mu \mathrm{m}$. Ascospores elongate-ellipsoid, 16.8-17.8-19.6 × 8.2-9.5-11.2 $\mu \mathrm{m}$, with one large internal oil drop. Paraphyses straight, 3-5 $\mu \mathrm{m}$ below, indistinctly enlarged at the clavate tips.

Specimens examined/sequenced: See Table 1.

Notes: This new species is nested in the /atra-pallescens lineage, as delineated by Skrede et al. (2017). It resembles H. lacunosa in the ribbed, whitish stipe, the greyish-black to black hymenium, and the greyish-black outer cap surface. The apothecial margin 
is generally free from the stipe. It genetically diverges from its sister species $H$. atra in two $h s p$, one $r p b 2$ and five LSU substitutions (cf. Fig. 1).

Helvella iberica Skrede \& T. Schumach. sp. nov. MycoBank MB834622. Fig. 6A, B.

Etymology: Referring to its occurrence on the Iberian Peninsula.

Typus: Spain, El Rasillo, 13 Apr. 2013, R. Martinez RM2373 (holotype O-F-256539).

Apothecium stipitate-capitate, cap $1.5-3.5 \mathrm{~cm}$ broad, irregularly saddle-shaped with 2 to 4 lobes, adnate; margin free, hymenium dark greyish black to black, even or wrinkled folded, receptacle paler, light grey to greyish black, smooth, with branching blunt ribs continuing from stipe. Stipe cylindrical, 2-4 cm high, 0.7-1.5 $\mathrm{cm}$ broad, whitish to greyish, with deep, longitudinal, undulating furrows and blunt ribs, with some \pm lacunae between. Medullary excipulum of loose textura intricata, hyphae 4-6 $\mu \mathrm{m}$ broad. Outer excipulum of textura angularis, individual cells 12-24 $\times$ 10-20 $\mu \mathrm{m}$, light brown-walled, outermost cells club-shaped to sub-capitate. Asci pleurorhynchous, $260-310 \times 15-21 \mu \mathrm{m}$. Ascospores elongate ellipsoid, 18.2-20.4-21.8 × 10.8-12.0-13.8 $\mu \mathrm{m}$, with one large internal oil drop. Paraphyses straight, 4-6 $\mu \mathrm{m}$ below, slightly bent at tips, enlarged to 7-9 $\mu \mathrm{m}$ at the clavate tips.

Specimens examined/sequenced: See Table 1.

Notes: Helvella iberica is nested in the /helvellula lineage, as delineated by Skrede et al. (2017) (cf. Fig. 1). It resembles H. juniperi in colour and stature (Filippa \& Baiano 1999). However, the free apothecial margin and five $h s p$ and one $r p b 2$ substitutions separate it from the latter. See also Fig. 4D and 'Notes' under $H$. inexpectata and $H$. semiobruta below.

Helvella inexpectata Skrede \& T. Schumach. sp. nov. MycoBank MB834623. Fig. 6G, $\mathrm{H}$.

Etymology: Referring to the unexpected occurrence of yet another species of the /helvellula lineage on the Iberian Peninsula.

Typus: Spain, Sojuela (La Rioja), 5 Mar. 2016, A. Ezquerro AE160305 (holotype O-F-256541).

Apothecium stipitate-capitate, cap black to greyish black, 1.5$4 \mathrm{~cm}$ broad, in young specimens bi- to trilobate, later more irregular in shape, margin gently involute, deflexed and adhered to the stipe, hymenium greyish black to black, receptacle surface greyish, smooth to furfuraceous, covered by tiny veins. Stipe cylindrical, $1.2-4 \mathrm{~cm}$ high, by $0.5-4.5 \mathrm{~cm}$ broad, hollow with a few internal chambers, concolourous with receptacle or paler above, whitish below, with six to eight blunt, longitudinal ribs and deep grooves. Medullary excipulum of dense textura intricata, hyphae 2.8-5.5 $\mu \mathrm{m}$ broad, pale brown-walled. Outer excipulum of densely packed rows of angular to club-shaped cells, 10-30 × 7-15 $\mu \mathrm{m}$, strongly constricted at septa, turning out perpendicular to receptacle surface. Asci pleurorhynchous, 280$320 \times 14-18 \mu \mathrm{m}$. Ascospores oblong ellipsoidal, 18.4-19.6-21.4 $\times 10.6-11.7-12.8 \mu \mathrm{m}$, with one large and several small internal guttules. Paraphyses straight, 2.5-3.5 $\mu \mathrm{m}$ below, enlarged to 5-6.5 $\mu \mathrm{m}$ at the clavate tips.

Specimens examined/sequenced: See Table 1.

Notes: Helvella inexpectata has a convex cap and a short greyish white stipe with longitudinal blunt ribs and deep grooves between. It is nested with $H$. helvellula, $H$. iberica, $H$. juniperi and $H$. semiobruta in a highly divergent /helvellula lineage of the /lacunosa clade (Fig. 1, cf. also Skrede et al. 2017). The species resembles $H$. juniperi (Fig. 4D) and $H$. iberica (Fig. 6A, B) in shape and colour, but has smaller and more oblong, narrow ascospores than these 'look alike' species. The Spanish specimens of $H$. iberica and the Italian holo- and isotype specimens of $H$. juniperi, newly sequenced by us, differ in three and two $h s p$, and one and two $r p b 2$ substitutions, respectively.

Helvella leucophaea (Batt.) Pers., Obs. mycol. 2: 19. 1799. Fig. $4 \mathrm{~A}$.

Basionym: Boletus leucophaea Battara, Fungorum Arimin.: 25. 1759.

Synonym: Helvella pithyophila Boud., J. Bot. 1: 218. 1887.

Illustrations: Trattinia (1809: pl. 28, as H. leucophaea Pers.), Boudier (1887: pl. 3; 1904b: $\mathrm{n}^{\circ}$. 17, pl. 227, as H. pithyophila).

Apothecium stipitate-capitate, apothecia irregular saddleshaped, 3-7 cm broad, hymenium pale olive brown, uneven bulged (wrinkled), margin crenate, reflexed, receptacle sub-pubescent, ochraceous brown, with low, branching, interconnected ribs. Stipe cylindrical, $6-10 \mathrm{~cm}$ high, by $1.5-3.5$ $\mathrm{cm}$ broad, grey to dark greyish brown, sub-pubescent, with deep, longitudinal, irregular furrows and sharp-edged ribs, inside of stipe with uneven-sized longitudinal chambers. Medullary excipulum of interwoven septate, brown, branching hyphae, 3-5 $\mu \mathrm{m}$ broad. Outer excipulum of textura angularis, cells mostly 10$20 \times 6-15 \mu \mathrm{m}$, outermost layer of cylindrical to club-shaped 3to 5-celled protruding hyphae, 10-15 $\mu \mathrm{m}$ broad. Asci cylindrical, pleurorhynchous, 290-350 × 14-16 $\mu \mathrm{m}$. Ascospores ellipsoid, with one large and numerous small internal oil drops, 16.218.8-20.4 × 10.2-10.8-12.0 $\mu \mathrm{m}$. Paraphyses subhyaline, 3-4 $\mu \mathrm{m}$ broad below, enlarged to $6-10 \mu \mathrm{m}$ at the irregular clavate tips, terminal cell thick-walled with incrusted, adhesive pigments.

Specimen examined/sequenced: See Table 1.

Notes: Helvella leucophaea resembles $H$. crispa in size and stature. However, the hymenium and stipe in fresh ascomata of the former are greyish to greyish brown, drying caramel brown. The two individuals from France and Spain are molecularly identical. Four consistent $r p b 2$ and two hsp substitutions separate $H$. leucophaea and its sister species $H$. crispa of the / crispa lineage (cf. Skrede et al. 2017).

Helvella macropus (Pers.) P. Karst., Not. Sällsk. F. Fl. Fenn. Förh. 11: 224. 1870. Fig. 8F.

Basionym: Peziza macropus Pers., Ann. Bot. (Usteri) 15: 26. 1795; Fr., Syst. Mycol. 2: 57. 1822.

Synonyms: See Skrede et al. (2017).

Illustrations: Dissing \& Nannfeldt (1966: figs 4, 5a-e, pl. III), Weber (1972: figs 23-24). 


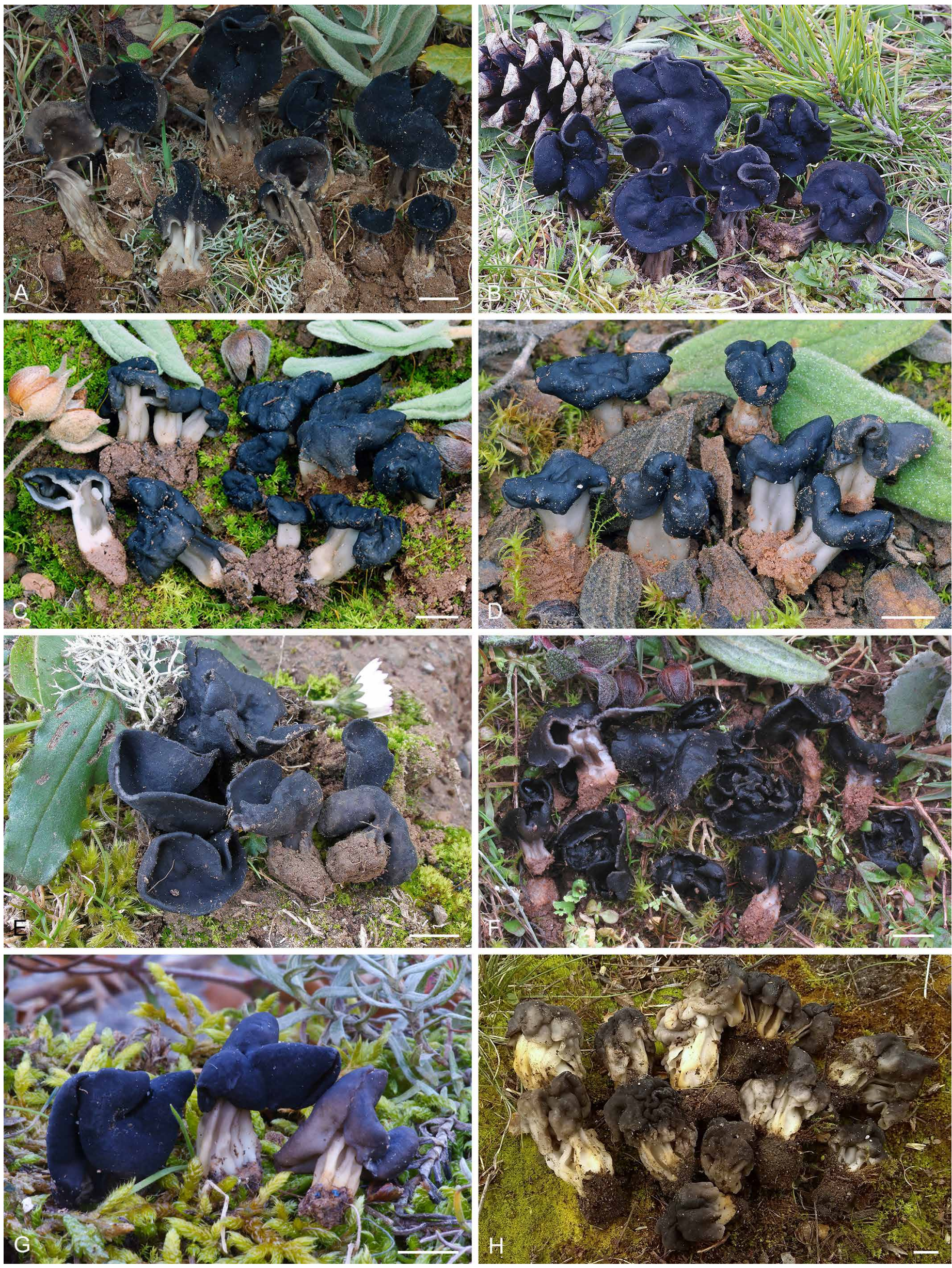

Fig. 6. Photographs of apothecia in their natural habitat. A. Helvella iberica GM2907 [H1016]. B. H. iberica RM2373 [H1018]. C. H. semiobruta RM2302 [H522]. D. H. semiobruta AC5335 [H524]. E. H. helvellula RM321 [H523]. F. H. helvellula LB15002101 [H525]. G. H. inexpectata RM1088 [H1017]. H. H. inexpectata AE160305 [H2621]. Scale bars $=1 \mathrm{~cm}$. All photographs taken by the collectors (confer Table 1). 
Apothecium stipitate-cupulate, cup \pm regular saucer-shaped, 1.5-3 cm broad, hymenium yellowish to greyish brown, receptacle concolourous, villose. Stipe terete, $2.5-12 \mathrm{~cm}$ high, $0.3-0.5 \mathrm{~cm}$ broad, pubescent. Medullary excipulum of loosely interwoven textura intricata, hyphae generally 4-6 $\mu \mathrm{m}$ broad, brownish, some hyphae with inflated cells 10-20 $\mu \mathrm{m}$ broad, constricted at septa. Ectal excipulum of textura intricata, innermost cells $10-30 \mu \mathrm{m}$ broad, turning into fascicled rows of cylindrical cells $20-35 \times 10-15 \mu \mathrm{m}$ in outermost excipulum, some hyphae extending into 50-200 $\mu \mathrm{m}$ long fascicled hyphoid hairs. Asci pleurorhynchous, 240-300 × 13-16 $\mu \mathrm{m}$. Ascospores ellipsoid-fusoid, with one large and two to three medium large internal guttules, 19.5-23.4-25.8 × 9-10.5-12.0 $\mu \mathrm{m}$. Paraphyses 3-4 $\mu \mathrm{m}$ below, gradually enlarged to 5-9 $\mu \mathrm{m}$ at the clavate tips.

Specimens examined/sequenced: See Table 1.

Notes: Our molecular survey of Helvella species in Europe and the Nordic countries confirms the existence of five or six phylogenetic species in the $H$. macropus morphospecies complex (including $H$. fibrosa), of which $H$. macropus is the most common species in Europe.
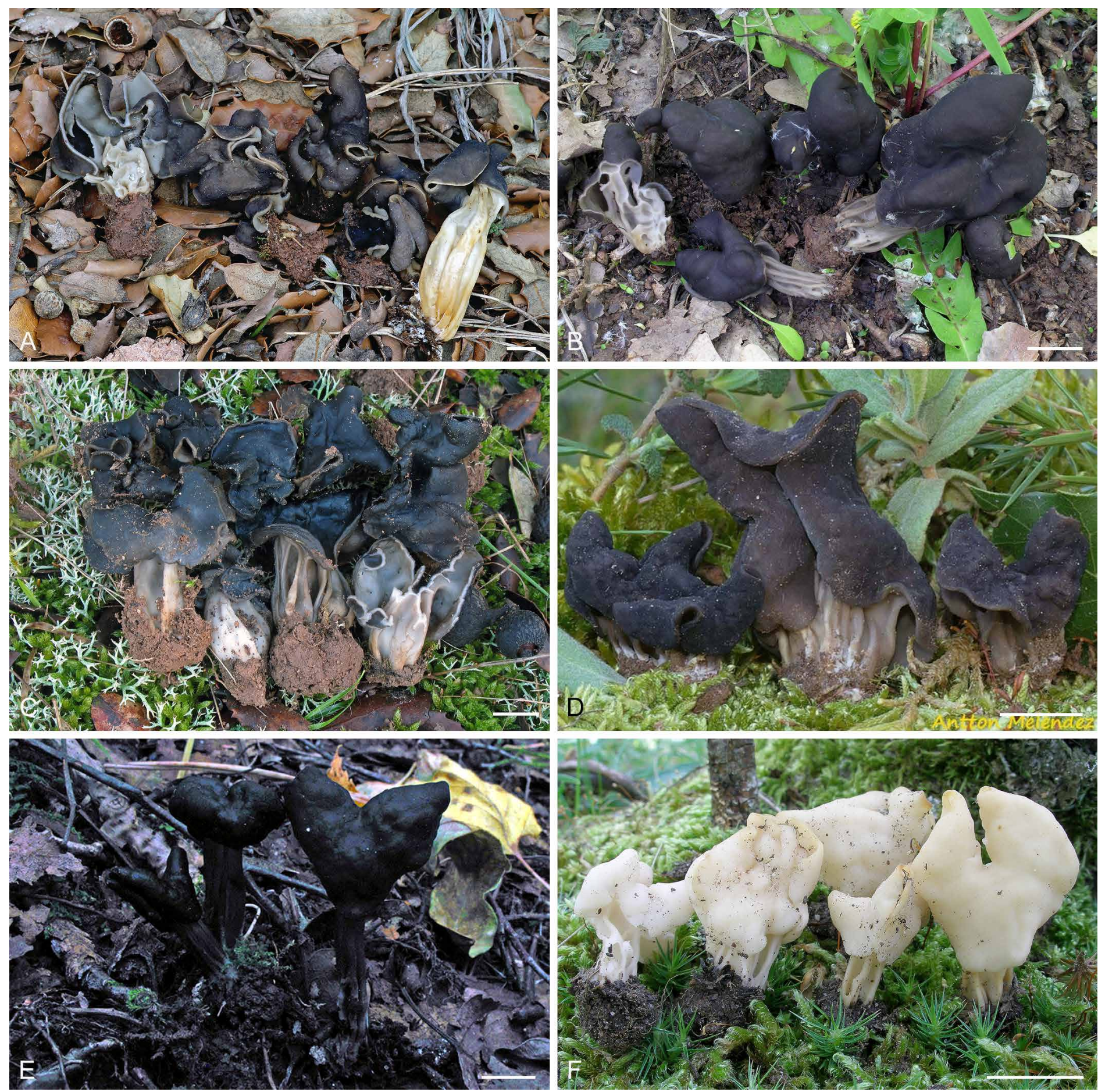

Fig. 7. Photographs of apothecia in their natural habitat. A. Helvella neopallescens LB14011801 [H1021]. B. H. neopallescens LB13062402 [H1026]. C. H. hispanica LB16022002 [H528]. D. H. hispanica PIPE-0833 [H1023]. E. H. terricola LB18092810 [H2978]. F. H. pallesens RM378 [H2638]. Scale bars $=1 \mathrm{~cm}$. All photographs taken by the collectors (confer Table 1 ). 
Helvella monachella (Scop.) Fr., Syst. Mycol. 2: 18. 1822. Fig. 8B. Basionym: Phallus monacella Scop., Fl. Carniol., ed. 2, 2: 478. 1772; Fr., Syst. Mycol. 2: 18. 1822 ('monachella' orth. mut.), non Helvella monacella Schaeff., Fung. Bavar. Palat. Nasc. 4: 106. 1774 ('Elvela'), nom. inval. (= Helvella sulcata Afzel.).

Synonyms: Helvella albipes Fuckel, Jahrb. Nassau. Vereins Naturk. 23-24: 334. 1870.

Helvella leucopus Pers., Mycol. Eur. 1: 213. 1822.

Illustrations: Fuckel (1870: pl.5, fig. 2), Dissing (1966b: fig. 38, as H. leucopus), Moravec (1980: pl. 4, as H. leucopus), Van Vooren (2010: 43, photo 12).

Apothecium stipitate-capitate, cap $1.5-4 \mathrm{~cm}$ broad, saddleshaped or irregularly lobate, deflexed, margin occasionally reflexed, free, hymenium dark brown to brownish black, receptacle smooth, whitish to pale greyish. Stipe terete, hollow, whitish, 3-7 cm high, 1-2 cm broad, often with irregular groves. Medullary excipulum of textura intricata, hyphae 3-6 $\mu \mathrm{m}$ broad, some hyphae heavily pigmented, blackish. Outer excipulum of textura angularis, cells cylindrical to club-shaped, $15-40 \times 6-20$ $\mu \mathrm{m}$, arranged in rows turning out perpendicular to receptacle surface. Asci pleurorhynchous, 260-310 $\times 15-18 \mu \mathrm{m}$. Ascospores ellipsoid, 20.6-22.0-23.8 × 12.7-14.1-15.2 $\mu \mathrm{m}$, with one large internal oil drop. Paraphyses straight, $3-5 \mu \mathrm{m}$ below, enlarged to 6-8 $\mu \mathrm{m}$ broad at the clavate tips.

Specimens examined/sequenced: See Table 1.

Note: The sequenced specimens from Spain have hsp and $r p b 2$ sequences identical to the rest of the sequenced specimens from Europe.

Helvella neopallescens Skrede \& T. Schumach. sp. nov. MycoBank MB834625. Fig. 7A, B.

Etymology: Referring to it being genetically similar to $H$. pallescens.

Typus: Spain, Rioja, Logrono, La Grajera, 7 Feb. 2015, R. Martinez RM2397 (holotype O-F-256550).

Apothecium stipitate-capitate, cap $2.5-4.5 \mathrm{~cm}$ broad, irregularly saddle-shaped, margin reflexed but attached to stipe at 3 to 4 points, hymenium dark brownish to greyish black, even, receptacle paler, greyish, smooth, with \pm anastomosing, delicate veins on the surface. Stipe whitish to greyish to dark grey, highly irregular in shape and length, \pm cylindrical, 2-6 cm high, 0.8$2.5 \mathrm{~cm}$ broad, with 5-7 longitudinal blunt-edged ribs, hollow, with large chambers inside. Medullary excipulum of densely interwoven textura intricata, hyphae 3-5 $\mu \mathrm{m}$ broad. Outer excipulum of irregular textura angularis, cells relatively broad, 15-35 × 12-25 $\mu \mathrm{m}$, outermost cells club-shaped, short-celled. Asci cylindrical, pleurorhynchous, 260-310 × 12.5-15 $\mu \mathrm{m}$. Ascospores obtuse ellipsoidal, 16.1-16.8-18.2 × 9.2-9.6-11.4 $\mu \mathrm{m}$, with one large internal oil drop. Paraphyses $3-5 \mu \mathrm{m}$ below, enlarged to $7-8 \mu \mathrm{m}$ broad at the clavate to spadiceiform tips.

Specimens examined/sequenced: See Table 1.

Notes: Helvella neopallescens is nested in the /atra-pallescens lineage, as delimited by Skrede et al. (2017). Morphologically, it resembles $H$. hispanica, $H$. fuscolacunosa, and $H$. lacunosa by the hollow, ribbed, and partly lacunose, whitish stipe and the contrasting brown to blackish cap, but is genetically distinct (cf. Fig. 1). It deviates from its morphologically dissimilar sister species $H$. pallescens in two hsp, one rpb2 and four LSU substitutions.

Helvella nigra Berg., Phytonom. univ. 1: t. 147. 1783. Fig. 4C. non Helvella nigra Peck, Bull. Torrey Bot. Club 26: 70. 1877, nom. illeg. (homonym).

See Skrede et al. (2017) for synonyms and typification.

Illustration: Bergeret (1783: pl. 147).

Apothecium stipitate-capitate, 2-6 cm across, cap saddle-shaped, bi- to trilobate, from 6 to $15 \mathrm{~cm}$ in height, apothecial margin adnate, firmly attached to the stipe at 4 to 6 points; hymenium wrinkled, dark grey to greyish black when fresh, drying darker, receptacle concolourous, smooth. Stipe concolourous or slightly paler, lacunose, receptacle surface concolourous or slightly paler, smooth, with distinct, branching ribs. Stipe $2.0-4.5 \mathrm{~cm}$ broad, naked, ribbed, ash grey to almost black, longitudinal ribs high and prominent, sharp, partly anastomosing and doubleedged, with deep 'holes' (lacunae) between ribs, stipe hollow and chambered inside. Medullary excipulum of textura intricata, hyphae 3-5 $\mu \mathrm{m}$ broad. Outer excipulum thin, of intermixed broad-celled textura intricata and textura globulosa-angularis, the layer light brown, outermost cells club-shaped, hyaline, 10-30 × 5-15 $\mu \mathrm{m}$, with loose outgrowth of few cells colouring intensely in cotton blue. Asci pleurorhynchous, 290-330 × 14$16 \mu \mathrm{m}$. Ascospores ellipsoid, uniguttulate, 16.5-17.8-19.0 $\times$ 10.4-11.1-12 $\mu \mathrm{m}$. Paraphyses straight, slightly bent at tips, light brown in the whole length, 3-4 $\mu \mathrm{m}$ broad below, enlarged to 6-8 $\mu \mathrm{m}$ at the tips.

Specimens examined/sequenced: See Table 1.

Notes: Helvella nigra is characterised by greyish black ashen colours, a tall, slender stature, a ribbed, lacunose stipe, and a reflexed and lobed cap with prominent ribs on the receptacle surface. The apically bent paraphyses (like a "golf-club") are characteristic under the lens. Eight $h s p$, three rpb2 and 25 LSU characters distinguish $H$. nigra and $H$. lacunosa.

Helvella pallescens Schaeff., Fungi Bavar. Palat. Nasc. 4: 114. 1774 ('Elvela'). Fig. 7F.

Synonym: Helvella sulcata $\beta$ (var.) pallescens (Schaeff.) Fr., Syst. Mycol. 2: 16. 1822.

Illustration: Schaeffer (1774: pl. 322).

Apothecium bilobate to campanulate to irregularly saddleshaped, cap $0.6-2 \mathrm{~cm}$ broad, by $2-3 \mathrm{~cm}$ high, underside glabrous, edge of cap adnate (reflexed) and fused with the stipe at 3 to 4 points, hymenium white to pale greyish drying brownish yellow; receptacle surface and stipe white to pale yellowish to brown, drying brown. Stipe long and slender, $0.5-1.5 \mathrm{~cm}$ broad, 4-6 cm high, hollow, with four to five longitudinal ribs and a few lacunae between. Medullary excipulum of an interwoven textura intricata, hyphae of variable thickness, 4-10 $\mu \mathrm{m}$ broad. Outer excipulum of textura globulosa to textura angularis, cells 20-40 $\mu \mathrm{m}$ diam, the outermost cells more elongated and prismatic 
giving rise to a cover of densely packed club-shaped cells on receptacle surface. Asci pleurorhynchous, 280-310 × 14-15 $\mu \mathrm{m}$, young asci with numerous cyanophilic ascospores with large pustules adhering to the spore wall. Ascospores broadly ellipsoid, 15.0-17.0-18.2 × 10.2-11.8-13.2 $\mu \mathrm{m}$. Paraphyses hyaline, $2-3 \mu \mathrm{m}$ broad, septate, gradually enlarged into irregular clavate tips, $6-10 \mu \mathrm{m}$ broad.

\section{Specimens examined/sequenced: See Table 1.}

Notes: Helvella pallescens is a slender, whitish to greyish species that has been confused with $\mathrm{H}$. lactea, with which it shares similar colours and microanatomy. Eight $r p b 2$ and nine hsp substitutions separate $H$. pallescens and $H$. lactea. The species is nested in the /lacunosa clade (Fig. 1).

Helvella panormitana Inzenga, Funghi siciliani 1: 41. 1865. Fig. $8 \mathrm{~A}$.

Illustrations: Inzenga (1865: pl. 4. f.1 $\left.1_{1-4}\right)$.

Apothecium stipitate-capitate, cap campanulate to bilobate, 1-2.5 cm broad, $1.5-3 \mathrm{~cm}$ high, long-stipitate, margin free, reflexed towards stipe, hymenium pale greyish brown, receptacle smooth, white or pale yellow, concolourous with stipe, drying brownish orange. Stipe $0.4-1 \mathrm{~cm}$ broad, by 3-15 $\mathrm{cm}$ high, solid to hollow, occasionally with grooves towards the base. Subhymenium and medullary excipulum of hyphae, 3-4 $\mu \mathrm{m}$ broad, embedded in an amorphous gelatinous matrix. Outer excipulum a mixture of textura intricata and textura angularis, hyphae up to $8 \mu \mathrm{m}$ broad, angular cells generally $25-40 \mu \mathrm{m}$ in diam., partly inflated to $60-70 \mu \mathrm{m}$ diam, outermost cells giving rise to densely packed rows of prismatic to club-shaped cells 10-20 $\mu \mathrm{m}$ broad, 10-30 $\mu \mathrm{m}$ long, outermost cell club-shaped and heavily staining in CB. Asci pleurorhynchous, 290-310 $\times$ 14-16 $\mu \mathrm{m}$. Ascospores ellipsoid, 19-22.2-24 × 11.5-12.7-13.5 $\mu \mathrm{m}$. Paraphyses ca. $3 \mu \mathrm{m}$ broad below, septate, light brown, gradually enlarged to $6-8 \mu \mathrm{m}$ at the clavate tips.

Specimens examined/sequenced: See Table 1.

Notes: Helvella panormitana was originally described from Sicily, Italy (Inzenga 1865). The species deviates from the morphologically similar H. elastica in 5 hsp, 11 rpb2 and 10 LSU substitutions. The species is widely distributed in Europe ( $c f$. Skrede et al. 2017).

Helvella pezizoides Afzel., Kongl. Vetensk. Acad. Nya Handl. 4: 308. 1783. - nom. sanct. Fig. 9A, B, D, F.

Synonym: Leptopodia pezizoides (Afzel.) Boud., Icon. Mycol., liste prelim.: 2. 1904.

\section{Illustrations: Afzelius (1783: pl. 10, f. 2), Dissing (1966b: 117).}

Apothecium involute, stipitate, $0.5-1.5 \mathrm{~cm}$ broad, with edge permanently deflexed, hymenium black, receptacle surface pubescent, ash grey. Stipe brownish black, terete, pubescent, 1-2 cm high, $0.4-0.7 \mathrm{~cm}$ broad. Medullary excipulum of loose textura intricata, hyphae hyaline, 4-7 $\mu \mathrm{m}$ broad, interspersed with some distinct brownish black hyphae. Outer excipulum of textura angularis, cells thick-walled, brownish, turning out in dense rows perpendicular to receptacle surface, outermost cells irregularly club-shaped, constricted at septa, forming twothree-celled brownish dense individual hyphae to $50 \mu \mathrm{m}$ long by $15 \mu \mathrm{m}$ broad. Asci pleurorhynchous, 260-300 × 12-15 $\mu \mathrm{m}$. Ascospores ellipsoid, 14.5-15.3-16.5 × 8.5-9.0-9.6 $\mu \mathrm{m}$, with one large guttule in rehydrated material. Paraphyses straight, 3.5-4.5 $\mu \mathrm{m}$ broad below, gradually enlarged to 5.5-7 $\mu \mathrm{m}$ at the clavate tips.

Specimens examined/sequenced: See Table 1.

Notes: Morphologically, $H$. pezizoides resembles $H$. fallax and $H$. pulla in colour, but the pubescent receptacle and stipe separate it from the two latter species. In an ongoing study of Helvella in the Nordic countries, we discovered an authentic collection of $H$. pezizoides in the fungarium of Stockholm (S), and a colour plate of $H$. pezizoides in the fungarium of Uppsala (UPS) both examined and prepared by Adam Afzelius himself. The original specimen in $S$ is three apothecia of Afzelius' original material mounted and glued to a sheet and filed under the name of Peziza (stipitata), a name which was also referred to by Afzelius in his original description of $H$. pezizoides (cf. Afzelius 1783, p. 308). The colour plate in UPS is a drawing of this fungarium sheet (now in S), which was also reproduced in an inverted version as a figure in the original work by Afzelius (1783, tab X, fig. 2). This figure was selected as a lectotype (iconotype) of $H$. pezizoides by Dissing (1966b). The original collection of Afzelius was tentatively referred to $H$. villosa $[=H$. fibrosa (Wallr.) Korf] by Dissing (1966b: 69).

Helvella phlebophoroides Skrede \& T. Schumach. sp. nov. MycoBank MB834601. Fig. 3E.

Etymology: Pertaining to the prominent ribbed (phlebus = veined) outer surface of the receptacle similar to that observed in H. phlebophora.

Typus: Spain, Rioja, Anguiano, 2 Jul. 2011, R. Martinez RM2193 (holotype O-F-256565).

Apothecium stipitate-capitate, saddle-shaped to plane, cap 1.5$3.5 \mathrm{~cm}$ broad, attached to stipe at two to three points, when fully developed with a deflexed and free margin, hymenium greyish black, surface even or wrinkled, receptacle smooth, pale grey to whitish. Stipe grey to greyish white, 3-6 cm high, $1-1.5 \mathrm{~cm}$ broad, with 4 to 7 partly double-edged, blunt longitudinal ribs and deep furrows with a few lacunae between, ribs extending onto the receptacle forming delicate, radial ribs and veins ( $c f$. Fig. $3 \mathrm{E}$ ). Medullary excipulum of dense textura intricata, hyphae 4-6.5 $\mu \mathrm{m}$ broad. Outer excipulum of a mixture of textura angularis/ intricata, the outermost cells bound in loosely interconnected rows of cells, brown-walled, $10-20 \times 5-12 \mu \mathrm{m}$, turning out perpendicular to receptacle surface, outermost cell club-shaped. Asci cylindrical with a lengthy narrow sterile portion below, pleurorhynchous, 280-320 × 12-15 $\mu \mathrm{m}$. Ascospores ellipsoid, with one large oil drop when fully mature, 15.2-16.6-17.8 $\times$ 9.0-9.6-10.4 $\mu \mathrm{m}$. Paraphyses straight, $4-5 \mu \mathrm{m}$ broad, enlarged to $6-8 \mu \mathrm{m}$ at the tips.

Specimens examined/sequenced: See Table 1.

Notes: Helvella phlebophoroides is sister species to $H$. sulcata in our phylogeny ( $c f$. Fig. 1). Four hsp and three $r p b 2$ characters 
separate the two species. The species occurs in Denmark as well (Table 1). Helvella phlebophoroides may be confused with $H$. phlebophora and $H$. queletiana, due to the prominent radiating ribs of the outer receptacle surface. However, $H$.
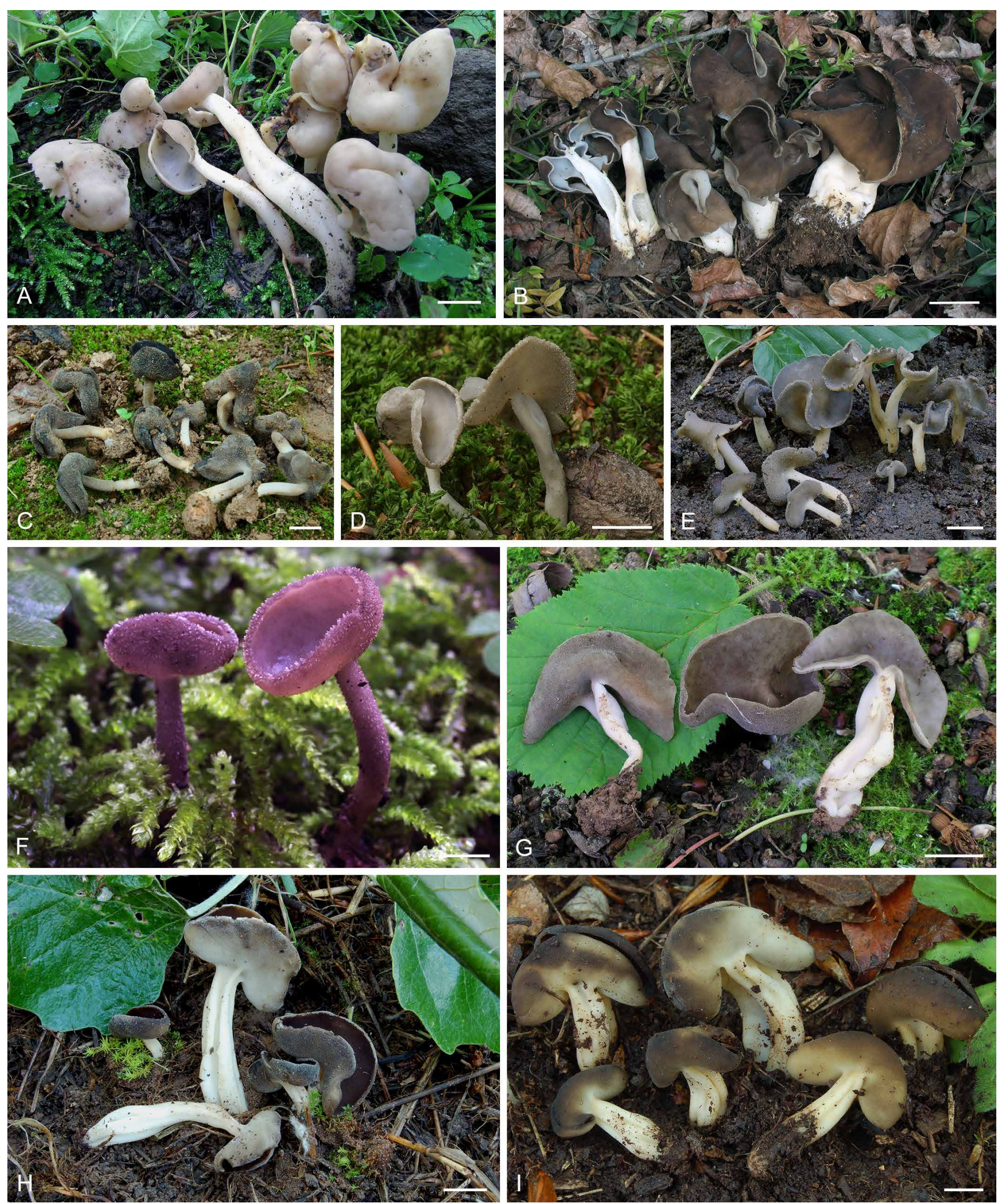

Fig. 8. Photographs of apothecia in their natural habitat. A. Helvella panormitana LB07101202 [H2627]. B. H. monachella LB150429 [H2631]. C. H. poculiformis GM1702 [H1944]. D. H. sublicia RM22 [H2637]. E. H. sublicia RM2286 [H1932]. F. H. macropus LB15091205 [H1933]. G. H. platypodia LB13061103 [H1939]. H. H. solitaria GM1011 [H1945]. I. H. solitaria GM2506 [H1946]. Scale bars = $1 \mathrm{~cm}$. All photographs taken by the collectors (confer Table 1). 
phlebophoroides, like $H$. queletiana has fewer and more distantly set, irregularly radiating ribs on the receptacle surface compared to $H$. phlebophora. These three species all form distinct phylogenetic groups. Helvella phlebophoroides and $H$. queletiana is separated by nine hsp, $10 \mathrm{rpb} 2$ and 19 LSU substitutions, and H. phlebophoroides and H. phlebophora by 10 hsp, 14 rpb2 and 20 LSU substitutions.

Helvella platypodia (Boud.) Donadini, Bull. Soc. linn. Provence 35: 136. 1985. [1984]. Fig. 8G.

Basionym: Cyathipodia platypodia Boud., Hist. Class. Discom. Eur.: 39. 1907.

Typus: Lectotype designated here (MycoBank MBT390951): Boudier, Icones Mycol. Livr. 22: $\mathrm{n}^{\circ}$. 467, pl. 241, as C. platypodia 1909a. Epitype designated here (MycoBank MBT390950): Spain, Rioja, Sorzano, under Corylus avellana, 11 Jun. 2013, L. Ballester LB13061103 (epitype O-F-256566).

Illustration: Boudier (1909a: n. 467, pl. 241, as C. platypodia).

Apothecium cupulate-stipitate, small to medium-sized, 1.5-3.5 $\mathrm{cm}$ broad, by $1-2.5 \mathrm{~cm}$ high, regular cupulate to saucer-shaped and recurved when fully mature, hymenium and receptacle greyish to olive grey, concolourous, receptacle and stipe pubescent, drying rusty brown, hymenium drying dark brown. Stipe whitish to yellowish, compressed (flattened - 'platypodia'), solid, to $3.5 \mathrm{~cm}$ high, $0.5-1.5 \mathrm{~cm}$ broad, with 2 to 3 longitudinal grooves. Medullary excipulum of textura intricata, hyphae 3-6 $\mu \mathrm{m}$ broad, septate. Outer excipulum of textura angularis, cells elongate club-shaped in rows, $20-30 \times 10-15 \mu \mathrm{m}$, cells in periphery constricted at septa, outermost cells protruding into scattered loose tufts of fascicled, multiseptate hyphae (hyphoid hairs), 40-150 $\mu \mathrm{m}$ long, by $10-25 \mu \mathrm{m}$ broad. Asci pleurorhynchous, 270-310 × 13-15 $\mu \mathrm{m}$. Ascospores ellipsoid, 16.5-18.1-19.0 × 11.0-11.9-12.5 $\mu \mathrm{m}$, with one large internal oil drop and some smaller guttules at the poles. Paraphyses 2-3.5 $\mu \mathrm{m}$ broad, not much enlarged to 5-6 $\mu \mathrm{m}$ at the tips.

Specimens examined/sequenced: See Table 1.

Notes: We have resurrected the name $H$. platypodia for this species, lectotypified by Boudier's plate (iconotype), and supported with an epitype from Spain, which contributes partial $h s p$ and $r p b 2$ sequences to the species. Helvella platypodia belongs in the /hypocrateriformis lineage, as delineated by Skrede et al. (2017).

Helvella platypodia is a small to medium-sized grey to olive grey species with a contrasting white, compressed, furrowed stipe. The ascoma turn rusty brown when dried, matching the colours and description (in dry condition) in Boudier (1909a), and then resembling miniature ascomata of Helvella solitaria (see this species below). The Spanish collection is on acid soil in association with Corylus avellana and Populus nigra. The species occurs in Denmark as well (cf. Table 1). Based on gross morphology in dried condition, $H$. platypodia has been intermixed with the genetically unrelated $H$. solitaria $(=H$. queletii) of the /acetabulum - solitaria lineage with less greyish but more brown-coloured hymenium and more elongate, larger ascospores.
Helvella poculiformis Skrede \& T. Schumach. sp. nov. MycoBank MB834627. Fig. 8C.

Etymology: Pertaining to the cup-shaped apothecia in this species.

Typus: Spain, Zaragoza, 10 Nov. 2009, G. Munoz GM1702 (holotype O-F-256567).

Apothecium stipitate-cupulate, 1-2.5 cm broad, by 1.5-3.5 $\mathrm{cm}$ high, regular cupulate to saucer-shaped, hymenium and receptacle dark grey to greyish, concolourous, receptacle drying rusty brown, hymenium dark brown. Stipe terete, cylindrical, whitish to greyish white, $0.3-0.5 \mathrm{~cm}$ broad. Medullary excipulum of textura intricata, hyphae brownish, 3-4 $\mu \mathrm{m}$ broad. Outer excipulum of textura angularis, cells elongate club-shaped of even size, $15-20 \times 8-15 \mu \mathrm{m}$, outermost cells extending into scattered multi-celled hyphae (hyphoid hairs), 30-80 $\mu \mathrm{m}$ long, 7-15 $\mu \mathrm{m}$ broad. Asci pleurorhynchous, 240-280 × 11.5-15 $\mu \mathrm{m}$, ascospores \pm obliquely arranged in asci. Ascospores ellipsoid, slightly narrowing towards the poles, 18.5-19.2-20.5 × 9.210.0-11.0 $\mu \mathrm{m}$, with one large and several minor internal guttules at the poles. Paraphyses $2.5-3.5 \mu \mathrm{m}$ broad, enlarged to $6-9 \mu \mathrm{m}$ at the slightly spadiceiform, clavate tips.

Specimen examined/sequenced: See Table 1.

Notes: Helvella poculiformis resembles $H$. sublicia in shape and colour and is nested in the /rivularis - sublicia lineage of Skrede et al. (2017). The ascoma is regularly cupulate to saucershaped, with a dark greyish black cup and a contrasting whitish to greyish, terete stipe. Helvella poculiformis differs from $\mathrm{H}$. sublicia in three $h s p$ and four rpb2 substitutions.

Helvella pulla Holmsk., Beata ruris otia Fung. Dan. 2: 49. 1799. - nom. sanct. Fig. 9C, E.

Synonym: Helvella fuliginosa Schaeff., Fung. Bavar. Palat. Nasc. 4: 113.1774.

Illustrations: Holmskjold (1799: pl. 26), Schaeffer (1774: pl. 320, as Helvella fuliginosa).

Apothecium stipitate-capitate, cap $0.5-1.5 \mathrm{~cm}$ broad, $0.5-1.5 \mathrm{~cm}$ high saddle-shaped, bilobate and involute (reflexed) throughout development, hymenium pale grey to medium grey, receptacle concolourous, subpubescent. Stipe grey, terete or slightly compressed, sub-pubescent, greyish, $3-6 \mathrm{~cm}$ long, $0.3-0.5 \mathrm{~cm}$ broad, firmly attached to deeply decayed wood. Medullary excipulum of loosely interwoven textura intricata, hyphae ca. 2.5-4.5 $\mathrm{mm}$ broad, subhyaline, intermixed with some broader, brown-walled hyphae. Outer excipulum of textura prismatica, hyphae light brown-walled, 5-15 $\mu \mathrm{m}$ broad, arranged in rows turning out perpendicular to receptacle surface, outermost cells club-shaped, 15-30 × 10-20 $\mu \mathrm{m}$. Asci pleurorhynchous, 275-310 $\times 13-15 \mu \mathrm{m}$. Ascospores ellipsoid, 17.6-18.3-19.0 × 10.6-11.4$12.0 \mu \mathrm{m}$. Paraphyses subhyaline, $3-4 \mu \mathrm{m}$ broad below, gradually enlarged to 8-12 $\mu \mathrm{m}$ at the tips.

Specimens examined/sequenced: See Table 1.

Notes: This grey to blackish species of the /fallax - pezizoides lineage may resemble $H$. poculiformis and $H$. sublicia (of the 
/ rivularis - sublicia lineage) in colour, however, both ascoma ontogeny (permanently saddle shaped and bilobate in $\mathrm{H}$. pulla versus cupulate to applanate to compressed in $H$. poculiformis and $H$. sublicia) and microanatomy (ascospore mean values $\underline{18.3}$ $\times \underline{11.4} \mu \mathrm{m}$ in $H$. pulla versus $\underline{19.2} \times \underline{10.0} \mu \mathrm{m}$ in $H$. poculiformis and $\underline{20.1} \times \underline{12.5} \mu \mathrm{m}$ in $\mathrm{H}$. sublicia) as well as molecular data easily discriminate among the three.
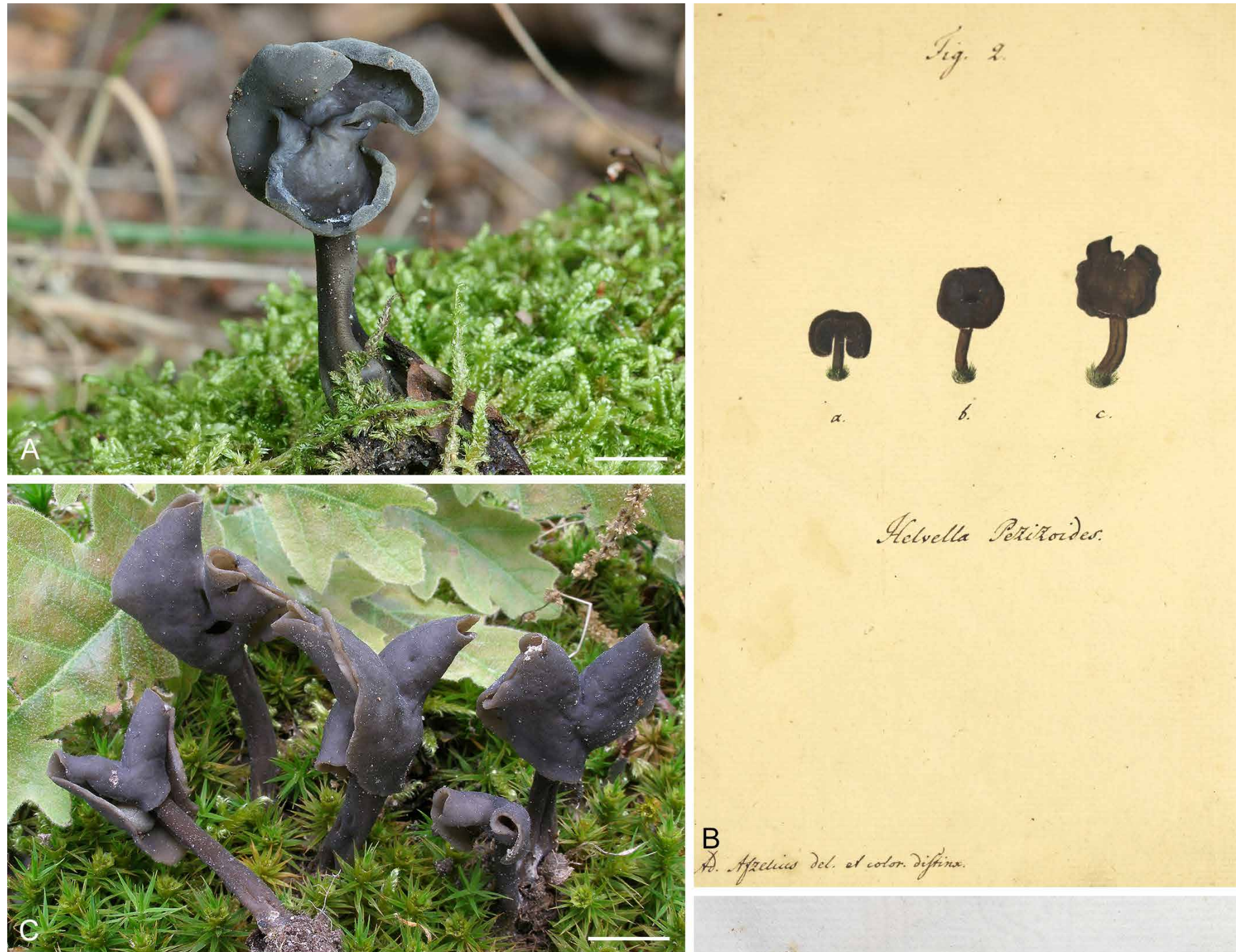

$$
\text { 1. Afpecian del er colon Diffine. }
$$


Fig. 9. Photographs of apothecia, an illustration and a fungarium specimen. A. Helvella pezizoides RM2274 [H2636]. B. Authentic plate of $H$. pezizoides deposited in the fungarium of Uppsala (UPS). C. H. pulla LB13061101 [H2629]. D. Original specimen of $H$. pezizoides, glued to cardboard in the fungarium of Stockholm (S). E. H. pulla RM1161 [H2635]. F. The envelope of the original material of H. pezizoides, annotated Peziza stipitata. Scale bars $=1 \mathrm{~cm}$. Photographs A, C and E are taken by the collectors (confer Table 1 ) and photographs B, D and F by Åsa Kruys. 
Helvella queletiana Sacc. \& Trav., in Sacc., Syll. Fung. 19: 850. 1910. Fig. 3D.

Synonyms: See Skrede et al. (2017).

Illustration: ? Weber (1972: fig. 34, as H. phlebophora?).

Apothecium stipitate-capitate, cap hemispheric, convex to flattened, 2-3.5 cm broad, $0.5-1.5 \mathrm{~cm}$ high, margin free to deflexed toward stipe, hymenium grey to light brownish grey, receptacle light grey to cream, drying darker, subtomentose, with conspicuous, branched, blunt ribs. Stipe $2.5-5 \mathrm{~cm}$ long, $0.8-$ $1.5 \mathrm{~cm}$ broad, pubescent, paler or concolourous with receptacle, inside chambered, outside with 3 to 5 double-edged, sharp ribs continuing onto the receptacle surface. Medullary excipulum of textura intricata, hyphae septate, branching, hyaline, 4-10 $\mu \mathrm{m}$ broad. Outer excipulum of angular to club-shaped cells arranged in a palisade towards the surface, individual cells $15-35 \times 5-20$ $\mu \mathrm{m}$, hyaline to brown-walled, outermost cells in rows forming hyaline hyphoid short-celled hairs. Asci pleurorhynchous, 270$320 \times 12-17 \mu \mathrm{m}$. Ascospores ellipsoid, 17.0-17.8-19.2 × 11.2$\underline{12.3}-13.5 \mu \mathrm{m}$. Paraphyses 3-4 $\mu \mathrm{m}$ broad below, subhyaline to pale brown-walled, at tips enlarged to 5-7 $\mu \mathrm{m}$ broad.

Specimens examined/sequenced: See Table 1.

Notes: Helvella queletiana is nested in an unsupported singlespecies lineage of the /lacunosa clade (clade B), as delineated by Skrede et al. (2017), a position retained in the present phylogeny (cf. Fig. 1). The photograph and description of Helvella phlebophora in Weber (1972, fig. 34) is suggestive of H. queletiana.

Helvella retinervis Skrede \& T. Schumach. sp. nov. MycoBank MB834628. Fig. 2I, J.

Etymology: Referring to the veined (nerved) receptacle surface forming an incomplete network (reticulum).

Typus: Spain, Gipuzkoa, San Sebastian, 21 May 2009, J.M. Lekuona (holotype ARAN3008363).

Apothecium shortly stipitate-cupulate, cup $1.5-3.2 \mathrm{~cm}$ broad, hymenium greyish brown, smooth, often wrinkled, receptacle subpubescent, paler, greyish to whitish, with prominent branching ribs and interconnected veins forming a \pm reticulate pattern, ribs reaching the margin or not, arising from a short stipe. Stipe indistinct, ribbed, $0.4-1 \mathrm{~cm}$ high. Medullary excipulum of tightly interwoven textura intricata, hyphae 3-6 $\mu \mathrm{m}$ broad. Outer excipulum of angular to prismatic cells, 10-20 $\times 5-20 \mu \mathrm{m}$ broad, protruding in a loosely interwoven fasciculate, 3- to 6-celled tufts. Asci cylindrical, pleurorhynchous, 240-280 $\times 12-16 \mu \mathrm{m}$. Ascospores broadly ellipsoid to oval, uniguttulate, 14.0-14.6-15.8 × 11.3-12.0-13.3 $\mu \mathrm{m}$, with one large internal oil drop. Paraphyses straight, $2.5-3.5 \mu \mathrm{m}$ broad below, enlarged to 5-7.5 $\mu \mathrm{m}$ at the clavate to subcapitate tips.

Specimens examined/sequenced: See Table 1.

Notes: The species belongs in the $H$. costifera morphospecies complex, but constitutes a lineage of its own in our phylogeny (cf. Fig. 1). Helvella retinervis is distinguished from $H$. costifera and $H$. calycina, by two $h s p$ and 12 rpb2, and four $h s p$ and 12 rpb2 substitutions, respectively. Helvella retinervis has also turned up among recently sequenced specimens of the $H$. costifera morpho-species complex from the fungarium in Stockholm (S), Sweden (see Table 1).

Helvella semiobruta Donadini \& Berthet, Bull. Soc. mycol. Fr. 91: 555. 1976. (1975). Fig. 6C, D.

Illustration: Donadini \& Berthet (1975: figs 1-8).

Apothecium stipitate-capitate, cap convex, $1.5-3 \mathrm{~cm}$ broad, in young specimens folded and convex, later bilobate or trilobate and irregular in shape, margin undulate, gently involute or straight, in mature specimens deflexed and welded to the attachment points of the stipe, hymenium smooth, even or gibbose, folded, black, receptacle surface smooth to furfuraceous, at first greyish white, then greyish black in old specimens, covered by branched ribs and veins. Stipe $1.2-4 \mathrm{~cm}$ high, $0.5-2 \mathrm{~cm}$ broad, hollow, with 1 to 3 internal chambers, outside with three to five blunt and broad ribs and grooves, concolourous with receptacle or paler above, whitish below, in premature specimens stipe compressed with less protruding ribs. Medullary excipulum of dense textura intricata, hyphae 2.8-6.6 $\mu \mathrm{m}$ broad, with pale brown walls. Outer excipulum of brownish rows of angular to prismatic cells, 10-30 $\times 7-15 \mu \mathrm{m}$ turning out perpendicular to receptacle surface. Asci pleurorhynchous, 300-370 × 14-18 $\mu \mathrm{m}$. Ascospores oblong ellipsoidal, $19.8-\underline{22.1}-24.5 \times 12.2-13.8-14.8 \mu \mathrm{m}$, with one large and several small internal guttules. Paraphyses straight, 3-4 $\mu \mathrm{m}$ below, enlarged to $6-9 \mu \mathrm{m}$ at the clavate tips.

Specimens examined/sequenced: See Table 1.

Notes: This Mediterranean species has a convex cap and a short greyish white stipe with a few longitudinal, blunt ridges and grooves. It is nested with $H$. helvellula, $H$. iberica, $H$. inexpectata and $H$. juniperi in a highly divergent lineage of the /lacunosa clade (Fig. 1, see also Skrede et al. 2017). A specimen from Gotland, Sweden, has been identified among specimens of the $H$. lacunosa morphospecies complex deposited in the fungarium of Stockholm (S). Filippa et al. (2013) gave an account of the morphology and ecology of the species in the Mediterranean region.

The Spanish specimens of $H$. semiobruta are all associated with Cistus albidus and collected from January to March between 500 to 700 m a.s.l. Helvella semiobruta may be confused with $H$. juniperi, with which it shares habitat and period of ascoma formation. In $\mathrm{H}$. juniperi the stipitate-capitate ascoma is more irregularly saddle-shaped and has more numerous, prominent, longitudinal ribs and deep furrows on a cavernous, hollow stipe. Genetically, three $h s p$ and three $r p b 2$ substitutions separate $H$. semiobruta and $H$. juniperi. Helvella semiobruta also shares habitat and fruiting time with $H$. helvellula, which is cupulate and never capitate as in $H$. semiobruta.

Helvella solitaria P. Karst., Bidr. Känn. Finl. Nat. Folk 19: 37. 1871. Fig. 8H, I.

Synonyms: Helvella queletii Bres., Rev. Mycol. 4: 211. 1882.

Helvella ulvinenii Harmaja, Karstenia 19: 42. 1979.

See Skrede et al. (2017) for additional synonyms.

Illustrations: Dissing (1964: fig. 9; 1966b: fig. 18, as H. queletii), Dissing \& Nannfeldt (1966: pl. 2: 2, as H. queletii), Weber (1972: 
figs 27-28, as H. queletii), Harmaja (1977a: fig. 1, 1979: fig. 8, as $H$. ulvinenii), Schumacher \& Mohn Jenssen (1992: 21 , as $H$. queletii).

Apothecium stipitate-cupulate, cup to saucer-shaped, laterally compressed, $2.5-5 \mathrm{~cm}$ broad, hymenium dark greyish brown to brownish black, even, receptacle concolourous or paler, delicately pubescent. Stipe $1.5-6 \mathrm{~cm}$ high, by $0.8-2 \mathrm{~cm}$ broad, whitish or pale greyish, with 3 to 6 blunt ribs and grooves continuing onto the base of the cup. Medullary excipulum of densely interwoven textura intricata, hyphae 3-7 $\mu \mathrm{m}$ broad. Outer excipulum of textura angularis, cells slightly elongate, 25-50 × 20-40 $\mu \mathrm{m}$, outermost cells giving rise to 3 to 6 -celled hyphae in fascicled tufts, outermost cells cylindrical to club-shaped, 10-26 × 8-14 $\mu \mathrm{m}$. Asci pleurorhynchous, 270-330 × 13-15 $\mu \mathrm{m}$. Ascospores ellipsoid, uniguttulate, 18.2-20.1-21.8 × 11.4-12.5-13.2 $\mu \mathrm{m}$. Paraphyses 3-4 $\mu \mathrm{m}$ broad below, brown-walled, with brownish granular content, enlarged to 5-8 $\mu \mathrm{m}$ at the clavate tips.

Specimens examined/sequenced: See Table 1.

Notes: The specimens from Spain show no intraspecific hsp and $r p b 2$ variation, as also observed among the Scandinavian populations (Skrede et al. 2017).

Helvella sublicia Holmsk., Beata ruris otia Fung. Dan. 2: 51. 1799. Fig. 8D, E.

Synonym: Helvella ephippium Lev., Ann. Sci. Nat. Bot., sér. 2, 16: 240. 1841.

See Skrede et al. (2017) for additional synonyms.

Illustrations: Holmskjold (1799: pl. 27), Léveillé (1841: pl. 15 fig. 7, as $H$. ephippium), Dissing \& Lange (1967: figs $1 a, 7 d$, as $H$. ephippium).

Apothecium stipitate-cupulate, at first cupulate and laterally compressed with inrolled margin, then expanding to saddleshaped, adnate or reflexed, occasionally applanate, $0.5-2 \mathrm{~cm}$ broad, hymenium greyish to dark grey, occasionally whitish, even, receptacle sub-pubescent to villose, concolourous with hymenium. Stipe solid, terete, or compressed with one or two inconspicuous grooves below, concolourous with cap or paler to whitish. Medullary excipulum of textura intricata, hyphae 3-5 $\mu \mathrm{m}$ broad, walls brownish, intermixed with some blackish hyphae. Outer excipulum of textura angularis, cells 20-44 × 8-25 $\mu \mathrm{m}$, outermost cells cylindrical to club-shaped in rows perpendicular to receptacle surface, $20-40 \times 10-15 \mu \mathrm{m}$, outermost cells protruding to tufts of fascicled hyphae forming the villi of receptacle. Asci cylindrical, pleurorhynchous, 260$300 \times 14-17 \mu \mathrm{m}$. Ascospores ellipsoid, uniguttulate, 18.8-20.2$21.5 \times 10.7-11.6-12.4 \mu \mathrm{m}$. Paraphyses $2-3 \mu \mathrm{m}$ below, slightly enlarged to $4-7 \mu \mathrm{m}$ at the clavate tips.

Specimens examined/sequenced: See Table 1.

Notes: Helvella sublicia differs from other saddle-shaped Helvella species in its greyish colours and pubescent receptacle surface. The $h s p$ and $r p b 2$ sequences of the Spanish and Nordic specimens are identical.

Helvella sulcata Afzel., K. svenska Vetensk.-Acad. Handl. 4: 305. 1783. - nom. sanct. Fig. 3A, B.
Synonyms: See Skrede et al. (2017) for additional synonyms.

Illustration: Afzelius (1783: tab. 1, fig. 1), Schaeffer (1763: pl. 162, as 'Elvela decima quarta').

Apothecium stipitate-capitate, cap 1-4 cm broad, 3-6 cm high, saddle-shaped, bi- to trilobate, adnate, margin attached to stipe at 3 to 4 points, hymenium black, even or slightly wrinkled, receptacle surface greyish brown, smooth, without ribs on receptacle surface. Stipe $2-5 \mathrm{~cm}$ high, $0.5-3 \mathrm{~cm}$ broad, (apothecial height : stipe height $=1: 1$ ), naked, prominently ribbed, ribs sharp and deep, partly double-edged and anastomosing, with deep 'holes' (lacunae) between, 4-6 along the circumference, almost no stipe flesh. Medullary excipulum of loose textura intricata, hyphae ca. 4-5 $\mu \mathrm{m}$ broad. Outer excipulum of angular to prismatic cells arranged in rows turning out perpendicular to receptacle surface, individual cells $8-15$ $\mu \mathrm{m}$, outermost cells more loosely arranged, club-shaped, 10-30 $\times$ 5-15 $\mu \mathrm{m}$. Asci cylindrical, pleurorhynchous, 290-320 × 13-16 $\mu \mathrm{m}$. Ascospores broadly ellipsoid, 14.8-16.2-16.8 × 10.5-12.1$13.2 \mu \mathrm{m}$. Paraphyses 3-4 $\mu \mathrm{m}$ broad, light brown below, medium brown above, enlarged to 5-6.5 $\mu \mathrm{m}$ at the clavate tips.

Specimens examined/sequenced: See Table 1.

Notes: Five $h s p$, nine $r p b 2$, and 15 LSU substitutions distinguish $H$. sulcata and $H$. lacunosa.

Skrede et al. (2017) lectotypified $H$. sulcata with an authentic figure (iconotype) from the original work by Afzelius (1783, tab 1 , fig. 1). A depiction of an authentic colour plate of $H$. sulcata prepared by Adam Afzelius himself, located in the fungarium of Uppsala (UPS), is shown in Fig. 3A. This colour plate constitutes the prototype for the figure of $H$. sulcata in Afzelius' work (Afzelius 1783, plate X, fig. 1).

Helvella terricola Skrede \& T. Schumach. sp. nov. MycoBank MB834629. Fig. 7E.

Etymology: "dwelling on soil" as opposed to its "look-alike" sister species $H$. palustris.

Typus: Spain, Huesca, Cerler, 28 Sep. 2018, F. Cervera \& L. Ballester LB18092810 (holotype O-F-256562).

Apothecium stipitate-capitate, cap 1.5-4 cm broad, 1-2 cm high, saddle-shaped, bi- to trilobate, deflexed but margin not attached to the stipe, hymenium greyish black, surface rugose with age, receptacle concolourous with hymenium or paler, glabrous or subtomentose, with ribs radiating from stipe apex. Stipe light grey to dark grey $3-7.5 \mathrm{~cm}$ long, $0.5-1.5 \mathrm{~cm}$ thick, slightly tapering above, solid, with 5 to 8 single- or double-edged longitudinal ribs. Medullary excipulum of textura intricata, hyphae hyaline, 4-8 $\mu \mathrm{m}$ broad. Outer excipulum of textura globulosa-angularis, cells 20-40 $\mu \mathrm{m}$ diam., hyaline or light brown-walled, the outermost cells more elongated and prismatic giving rise to a palisade of densely packed club-shaped cells turning out perpendicular to receptacle surface. Asci pleurorhynchous, $260-320 \times 12-15$ $\mu \mathrm{m}$. Ascospores ellipsoid, 15.0-17.8-19.5 × 10.8-11.5-12.6 $\mu \mathrm{m}$. Paraphyses light brown-walled, 2-3 $\mu \mathrm{m}$ broad, septate, gradually enlarged into an irregular clavate tip, 5-10 $\mu \mathrm{m}$ broad.

Specimen examined/sequenced: See Table 1. 
Notes: Helvella terricola resembles $H$. palustris in shape and colour, but differs genetically in three $h s p$ and three $r p b 2$ substitutions. The two species differ substantially in ecology; $H$. palustris grows in minerotrophic fens and marshes while $H$. terricola grows on naked, moist soil.

\section{DISCUSSION}

This follow-up study of Dissingia and Helvella of species from Spain focuses on Mediterranean South European species and adds to the current knowledge of the species composition and diversity of Helvella in Europe. This study complements the previous synopsis by Skrede et al. (2017) which was primarily focused on North European species. The Spanish samples amount to 31 species of Dissingia (1) and Helvella (30) and in total we add 11 species to the list of European helvellas, of which nine are described as new. Altogether, 67 species are now re-evaluated and molecularly characterized from Europe (Skrede et al. 2017, Løken et al. 2019). Two of the newly described species are also found in other European countries, i.e. H. retinervis in Sweden and H. phlebophoroides in Denmark (cf. Table 1). It is worth mentioning that $H$. semiobruta, with a mainly South European distribution, has been detected from the island of Gotland, Sweden, which has a geology and climate comparable to that of the Mediterranean countries (cf. Table 1). The diversity illustrated in our survey is astonishing based on the limited number of collections (115) available. This underlines the extent of the unexplored diversity of Helvella and is highly suggestive that many more species of Helvella await discovery and description, in particular in regions where few collections have been made and are available in fungaria.

The Spanish samples also highlight the extensive radiation and diversification of e.g. the /helvellula lineage. This highly divergent lineage of the /lacunosa clade detected by Skrede et al. (2017), included three species, i.e. H. helvellula, H. semiobruta and $H$. juniperi. In the present outline, after incorporation of two additional species, i.e. $H$. iberica and $H$. inexpectata, this lineage comprises five species (cf. Fig. 1). It is noteworthy that $H$. juniperi, which is known with certainty from Italy and Portugal (cf. Table 1), did not turn up among the Spanish samples. Instead, the two new species $H$. iberica and $H$. inexpectata were detected, apparently sharing the same type of habitat as $H$. juniperi. It is expected that $H$. juniperi is also present in Spain. Moreover, the morphological diversification of species of this lineage is remarkable, considering the common ancestry of the group. Both stipitate and sessile, as well as cupulate and capitate species characterised have derived among these genetically very closely related species.

\section{ACKNOWLEDGEMENTS}

We thank all the collectors for this study, both for collecting the material, but also for taking excellent photographs of fresh ascomata to be published in the synopsis. We thank curator Raffaella Trabucco at the MCVE Herbarium for the arrangement of loan of holo- and paratype material of $H$. juniperi, and assistant Giovanni Robich at MCVE for sending an in situ photograph of the holotype specimen of H. juniperi to be published. The help from curator Åsa Kruys at the UPS Fungarium who has taken photographs of one original collection of Helvella pezizoides and authentic illustrations (plates) of Afzelius' Helvella pezizoides and $H$. sulcata deposited in the UPS Fungarium to be presented here is gratefully acknowledged. We thank Prof. Donald $H$. Pfister and one anonymous reviewer for constructive comments and valuable corrections to an earlier version of this manuscript. Funding for this research was provided by a grant from the Norwegian Biodiversity Information Centre to T.S. and I.S. (grant no. 45/15).

Conflict of interest: The authors declare that there is no conflict of interest.

\section{REFERENCES}

Abbott SP, Currah RS (1997). The Helvellaceae: systematic revision and occurrence in northern and northwestern North America. Mycotaxon 62: 1-125.

Afzelius A (1783). Svamp-slägtet Helvella. Kungliga Vetenskapsakademiens Nya Handlingar 4: 299-313, 1 pl.

Avise JC, Ball Jr RM (1990). Principles of genealogical concordance in species concepts and biological taxonomy. Oxford Surveys in Evolutionary Biology 7: 45-67.

Battara AJA (1759). Fungorum Agri Ariminensis Historia. 2nd ed., Faventiae: Typus Martinianis, Austria.

Bergeret J (1783). Phytonomatotechnie universelle. Vol. 1. Paris, France.

Boudier [JL] E (1887). Notice sur les Discomycètes figurés dans les dissins inédits de Dunal conservés à la Faculté de Montpellier. Bulletin de la Société mycologique de France 3: 88-96. pl. 8.

Boudier [JL] E (1904a). Icones Mycologicae - liste préliminaire des noms des 600 espèces de Champignons qui doivent être figurés dans les six series de Boudier, Icones Mycologicae, 4 pp., Paul Klincksieck, Paris, France.

Boudier [JL] E (1904b). Icones Mycologicae, livr. 1. Klincksieck, Paris, France.

Boudier [JL] E (1906). Icones Mycologicae, livr. 8. Klincksieck, Paris, France.

Boudier [JL] E (1908a). Icones Mycologicae, livr. 18, Klincksieck, Paris, France.

Boudier [JL] E (1908b). Icones Mycologicae, livr. 20, Klincksieck, Paris, France.

Boudier [JL] E (1909a). Icones Mycologicae, livr. 22, Klincksieck, Paris, France.

Boudier [JL] E (1909b). Icones Mycologicae, livr. 24, Klincksieck, Paris, France.

Calonge FD, Arroyo I (1990). Notes on the genus Helvella in Spain. Mycotaxon 39: 203-217.

Caroti V, Baiano G, Filippa M (2007). Una species tipicamente mediterranea presente anche in Italia: Helvella helvellula. Mycologia Montenegrina 10: 31-48.

Dettman JR, Jacobson DJ, Turner E, et al. (2003). Reproductive isolation and phylogenetic divergence in Neurospora: comparing methods of species recognition in a model eukaryote. Evolution 57: 2721-2741.

Dissing H (1964). Studies in arctic and subarctic Discomycetes. I. The Genus Helvella. Botanisk Tidsskrift 60: 108-128.

Dissing H (1966a). A revision of collections of the genus Helvella $\mathrm{L}$. ex St-Amans emend. Nannf. in the Boudier Herbarium. Revue de Mycologie 31: 189-224, pl. 1-4 (figs. 8-11).

Dissing H (1966b). The genus Helvella in Europe with special emphasis on the species found in Norden. Dansk Botanisk Arkiv 25: 1-172.

Dissing H (1972). Specific and generic delimitation in the Helvellaceae. Persoonia 6: 425-432.

Dissing H (2000). Pezizales Bessey. In: Hansen, L, Knudsen, H (eds.). Nordic Macromycetes Vol. 1. Ascomycetes: 55-127. Nordswamp, Copenhagen, Denmark. 
Dissing H, Lange M (1967). Notes on the genus Helvella in North America. Mycologia 59: 349-360.

Dissing H, Nannfeldt JA (1966). Helvella cupuliformis sp. nov., H. villosa (Hedw. ex O. Kuntze) comb. nov., H. macropus (Pers. ex Fr.) Karst., and their allies. Svensk Botanisk Tidskrift 60: 325-337.

Donadini, JC (1985). Étude des Discomycètes (I). Additif et commentaires. Bulletin de la Société Linnéenne de Provence 35: 131-138. (1984)

Donadini JC, Berthet P (1975). Une Helvelle nouvelle: Helvella semiobruta nov. sp. Bulletin de la Société mycologique de France 91: 553-555.

Durieu MC (1849). Flore d'Algérie. Exploration scientifique de l'Algerie 1: 441-600.

Edgar, RC (2004) MUSCLE: multiple sequence alignment with high accuracy and high throughput. Nucleic Acids Research 32: 17921797.

Filippa M, Baiano G (1999). Helvella juniperi sp. nov. Nuova specie raccolta sul litorale tirrenico. Rivista di Micologia 42: 99-118.

Filippa M, Baiano G (2011). Helvella atra König: Fries nomenclatura e tipificazione. Ascomycete.org. 2 (4): 57-64.

Filippa M, Baiano G, Baglivo A, et al. (2013). Helvella semiobruta: rivulatazione di una specie mediterránea. Rivista di Micologia 2013 (3): 195-210.

Fuckel L (1870). Symbolae mycologicae. Beiträge zur Kenntnis der rheinischen Pilze. Jahrbücher des Nassauischen Vereins für Naturkunde 23-24: 1-459. (1869-1870)

Gillet GC (1879). Champignons de France. Les Discomycètes 1. Alencon, France.

Häffner J (1987). Die gattung Helvella, morphologie und taxonomie. Beihefte zur Zeitschrift für Mykologie 7: 1-165.

Hansen K, Schumacher T, Skrede I, et al. (2019). Pindara revisited evolution and generic limits in Helvellaceae. Persoonia 42: 186-204.

Harmaja $\mathrm{H}$ (1977a). A note on Helvella solitaria (syn. $H$. queletii) and $H$. confusa n. sp. Karstenia 17: 40-44.

Harmaja $H$ (1977b). A revision of the Helvella acetabulum group (Pezizales) in Fennoscandia. Karstenia 17: 45-58.

Harmaja H (1979). Studies on cupulate species of Helvella. Karstenia 19: $33-45$.

Holmskjold T (1799). Beata ruris otia Fungis Danicis impensa 2. København, Denmark.

Inzenga G (1865). Funghi Siciliani. Centuria prima. Palermo, Italy.

Landeros F, Korf, RP (2012). Nomenclatural notes 13. An incorrect neotype designation and provision for a lectotype and an epitype for Helvella fusca. Mycotaxon 119: 431-438.

Landeros F, Iturriaga T, Guzmán-Dávalos L (2012). Type studies in Helvella (Pezizales) 1. Mycotaxon 119: 35-63.

Landeros F, Iturriaga T, Rodriguez A, et al. (2015). Advances in the phylogeny of Helvella (Fungi: Ascomycota), inferred from nuclear ribosomal LSU sequences and morphological data. Revista Mexicana de Boversidad 86: 856-871.

Léveillé JH (1841). Description de quelques espèces nouvelles des champignons. Annales des Sciences Naturelles Botanique, 2e Série 16: 235-242, pl. 14-15.
Løken SB, Skrede I, Schumacher T (2020). The Helvella corium species aggregate in Nordic countries - phylogeny and species delimitation. Fungal Systematics and Evolution 5: 169-186.

Moravec J (1980). Helvella leucopus Pers. in Czechoslovakia. (Discomycetes, Helvellaceae). Ceska Mykologie 34: 214-216, pl. IV.

Nannfeldt JA (1932). Bleka Stenmurklan, Gyromitra gigas (Krombh.) Cke. Friesia 1: 34-45.

Nannfeldt JA (1937). Contributions to the mycoflora of Sweden. 4. On some species of Helvella, together with a discussion of the natural affinities within Helvellaceae and Pezizaceae trib. Acetabuleae. Svensk Botanisk Tidskrift 31: 47-66, 2 plates.

Oeder GC (1770). Abbildungen der Pflanzen, welche in den Königreichen Dännemark und Norwegen, in den Herzogthümern Schlesswig und Holstein, und in den Grafschaften Oldenburg und Delmenhorst wild wachsen, zu Erläuterung des unter dem Titel Flora Danica, auf königl. Befehl veranstalteten Werkes von diesen Pflanzen / herausgegeben von dem Verfasser des bemeldten Werkes Georg Christian Oeder, Doctor der Arzenenkunst [sic] und Königlichen professor der Botanik. Flora Danica 3(9). Copenhagen, Denmark.

Schaeffer JC (1763). Fungorum qui in Bavaria et Palatinatu circa Ratisbonam nascuntur icones nativis coloribus expressae. Tomus 2. Henrici Godofredi Zunkelii, Ratisbonae, Germany.

Schaeffer JC (1774). Fungorum qui in Bavaria et Palatinatu circa Ratisbonam nascuntur icones nativis coloribus expressae. Tomus 4. Henrici Godofredi Zunkelii, Ratisbonae, Germany.

Schumacher T, Mohn Jenssen K (1992). Discomycetes from the Dovre Mountains, Central South Norway. Arctic and alpine fungi, Vol. 4. Soppkonsulenten A/S, Oslo, Norway.

Skrede I, Carlsen T, Schumacher T (2017). A synopsis of the saddle fungi (Helvella: Ascomycota) in Europe - species delimitation, taxonomy and typification. Persoonia 39: 201-253.

Stamatakis A (2006). RAxML-VI-HPC: maximum likelihood-based phylogenetic analyses with thousands of taxa and mixed models. Bioinformatics 22: 2688-2690.

Taylor JW, Jacobson DJ, Kroken S, et al. (2000). Phylogenetic species recognition and species concepts in fungi. Fungal Genetics and Biology 31: 21-32.

Trattinia L (1809). Die essbaren Schwämme des Oesterreichischen Kaiserstaates. Wien \& Trieste, Austria.

Van Vooren N (2010). Notes sur le genre Helvella L. (Ascomycota, Pezizales). 1. Le sous-genre Elasticae. Bulletin mycologique et botanique Dauphiné-Savoie 199: 27-60.

Van Vooren N (2014). Notes sur le genre Helvella L. (Ascomycota, Pezizales). 2. Les sous-genres Cupuliformes et Macropodes. Bulletin mycologique et botanique Dauphiné-Savoie 212: 29-47.

Wang X-C, Liu T-Z, Chen S-L, et al. (2019). A four-locus phylogeny of rib-stiped cupulate species of Helvella (Helvellaceae, Pezizales) with discovery of three new species. MycoKeys 60: 45-67.

Weber NS (1972). The genus Helvella in Michigan. The Michigan Botanist 11: 147-201.

Weber NS (1975). Notes on western species of Helvella. I. Beihefte Nova Hedwigia 51: 25-38, pl. 7-8. 